Portland State University

PDXScholar

6-7-1978

\title{
The Effects of a Child's Serious Illness Upon His or Her Siblings
}

Kathleen Bales

Portland State University

Follow this and additional works at: https://pdxscholar.library.pdx.edu/open_access_etds

Part of the Social Work Commons

Let us know how access to this document benefits you.

\section{Recommended Citation}

Bales, Kathleen, "The Effects of a Child's Serious Illness Upon His or Her Siblings" (1978). Dissertations and Theses. Paper 2690.

https://doi.org/10.15760/etd.2686

This Thesis is brought to you for free and open access. It has been accepted for inclusion in Dissertations and Theses by an authorized administrator of PDXScholar. Please contact us if we can make this document more accessible: pdxscholar@pdx.edu. 
THE EFFECTS OF A CHILD'S SERIOUS

ILLNESS UPON HIS OR HER SIBLINGS

by

KATHLEEN BALES

A practicum submitted

in partial fulfillment.

of the requirements

for the degree of

MASTER OF SOCIAL WORK

PORTLAND STATE UNIVERSITY 
Practicum approved by:

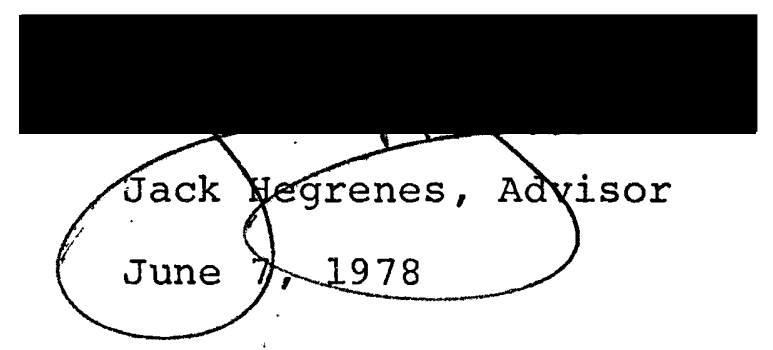




\section{ACKNOWLEDGMENTS}

I would like to thank the children and parents who participated in this study. Their co-operation and eagerness to help under, what for them, were often personally difficult and frustrating circumstances, is greatly appreciated.

To Dr. Robert Neerhout, Chairman of Department of Pediatrics, University of Oregon Health Sciences Center, I would like to extend a special thanks. His suggestions concerning the method of inquiry and his help locating the families of seriously ill children were of invaluable assistance in this study.

I especially want to thank my advisor, Jack Hegrenes, Ph.D., Associate Professor and Social Work Training Director of Crippled Children's Division, University of Oregon Health Sciences Center. Dr. Hegrenes' insight and gentle good humor helped smooth even the roughest bumps along the way. His assistance and encouragement in this endeavor are truly appreciated. To my family I want to extend an especially warm thanks for all they have invested in this project. My parents' patience, encouragement and long hours of babysitting made this study possible. My three children were, perhaps, the most understanding of all. Not only 
did they, encourage me "to finish my homework" each evening, but they practiced on their violins and trumpet just a little bit softer so I could "think". 
TABLE OF CONTENTS

PAGE

ACKNOWLEDGMENTS . . . . . . . . . . . . . . i ii

LIST OF TABLES . . . . . . . . . . . . . . vi

CHAPTER

I PURPOSE AND OVERVIEW . . . . . . . . . . I 1

II Literature Review. . . . . . . . . . 3

III METHOD OF INQUIRY . . . . . . . . 37

IV PRESENTATION OF DATA . . . . . . . . . 41

V DISCUSSION AND RECOMMENDATIONS • • . • 68

BIBLIOGRAPHY. • • . . . . . . . . . . 80

APPENDIX. . . . . . . . . . . . . . .

A CONSENT FORM . . . . . . . . . . 85

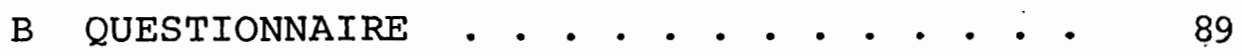


IIST OF TABLES

TABLE

PAGE

I DEMOGRAPHIC DATA CONCERNING SIBS OF SERIOUSLY . . . 43 IIL CHILDREN

II WHO FIRST TOLD CHILD OF SIBLING'S ILLNESS. . . . . . 44

III DESIRE TO KNOW OF SIBLING'S ILLNESS ........... 45

IV LENGTH OF TIME BEFORE SIBS WERE TOLD OF DIAGNOSIS. 45

V FREQUENCY OF FAMILY DISCUSSIONS ABOUT SIB'S ILLNESS 47

VI DESIRE TO TALK ABOUT SIB'S ILLNESS............ 48

VII CHANGE IN SIB'S RESPONSIBILITIES SINCE DIAGNOSIS.. 49

VIII CHANGE IN SIB'S SCHOOL LIFE SINCE DIAGNOSIS..... 5 I

IX FREQUENCY OF VISITS WITH FRIENDS SINCE DIAGNOSIS.. 52

$x$ DESIRE TO HELP CARE FOR S.ICK SIB............. 53

XI PARENTS' TREATMENT OF ALL CHILDREN SINCE DIAGNOSIS 54

XII AMOUNT OF TIME FAMILY SPENDS TOGETHER SINCE DIAGNOSIS 58

XIII CHILDREN'S PERCEPTION OF FAMILY FEELING STATE.... 60

XIV SIBLING'S PERCEIVED CLOSENESS TO PARENTS SINCE... 62 DIAGNOSIS

XV SIBLING'S CLOSENESS TO SICK BROTHER OR SISTER.... 63 SINCE DIAGNOSIS

XVI SIBLING'S CONCERN FOR OWN HEALTH............. 64

XVII SIBLING'S DESIRE TO TAKE SICK BROTHER OR SISTER'S. 66 PLACE 
CHAPTER I

PURPOSE AND OVERVIEW

In an effort to prevent serious psychological damage to individuals and families due to illness or disability, professionals in the health field have studied every aspect of one'shealth. From the "traumatic violence" of birth to the painful complexities of death and dying, the emotional health of human beings has been observed, recorded and analyzed. Despite the breadth of this voluminous research, one area of interest merits more thorough study and evaluation. In order to more fully understand the intricacies of health and illness we need to know more about the effect one seriously ill child has upon the emotional health of his or her siblings.

This study was conducted to gather more information about this important area of human experience. The focus was specifically aimed at the interaction between the parents of a sick child and his or her siblings. The study addressed the following question, in particular: Do the ways in which parents cope with a seriously ill child make a difference in the way siblings view the closeness in the family or their own self-concept?

From an increased awareness of the dynamics involved in serious childhood illness professionals in 
the health field can gain the necessary information to provide more comprehensive programs of assistance and to develop more effective methods of intervention. Among the potential benefits available to the families of the sick children are: improved child management and family interaction and the development of more adaptive coping skills. 


\section{CHAPTER II}

\section{IITERATURE REVIEW}

One of the most immediate and obvious facts to be revealed by a review of the literature is the recent, and as yet, still tentative nature of the approach to the issues surrounding death and dying. In the past our culture's avoidant attitudes toward the subject inhibited scientific investigations and produced an aura of silence around one of life's most certain experiences. With the advent of Elizabeth Kubler-Ross' historic work entitled "On Death and Dying" the topic was opened up for general discussion and scientific study alike. The last ten years have yielded many advances in understanding the complexities of death and dying. Numerous articles and books can be found on the subject, yet much remains to be learned about a sibling's reactions to childhood death. The following review is a synopsis of the current literature concerning not only the particular issue of sibling reactions, but also of family adjustment and coping in the face of life-thretening illness.

Goldberg (1973). believes that there are consequent reactions of the family as a unit to the actual or anticipated loss of one of its members. ${ }^{1}$ There are specific family readjustment tasks which are distinct from what we 
recognize as individual mourning tasks. To understand human behavior in relation to life-threatening situations both individual and familial tasks need to be taken into consideration.

According to Goldberg the basis of family crisis is that "the situation cannot be easily handled by the family's commonly used problemsolving mechanisms, but forces the employment of novel patterns." These are necessarily within the range of the family's capacities, but may be patterns never called into operation in the past. However, not. every stress becomes a crisis and Goldberg lists three variables which determine whether a stress event results in a crisis for the family.

1.) the hardships of the situation or event itself.

2.) The resources of the family: its role structure, flexibility and previous history with crisis.

3.) the definition the family makes of the event: that is whether the members treat the event as if it were or were not a threat to their status, goals and objectives. ${ }^{2}$

There are two characteristics of death as a stress event which make it readily convertible into a crisis situation: 1) the stark finality of the situation - irretrievable loss 
of a human being, and 2) death is not a frequent occurrenceit is a novel situation because there is often little prior experience.

If this kind of crisis does exist for a family, certain tasks are part of the anticipatory or actual coping mechanisms required of a family according to Goldberg. The first task centers around role reorganization which is different from role change. In this case, it is a matter of who will fulfill the specified responsibilities previously met by the ill member of the family. This task must be considered even during the period of illness as the individual relinquishes those responsibilities he or she can no longer meet. The second task for the family in crisis is to increase solidarity. Some families are more successful than others at increasing solidarity in times of trouble. Depending upon the coping mechanisms of the family and the ability of the family to manage stress, the family. may become more unified during a crisis or they may become more polarized and remote from one another. The third task for the family is object replacement. As the ill individual becomes more. incapacitated and withdrawn the family must replace its investment in that person. Goldberg believes parents often deal with the loss of a child by investing additional emotional energy in the remaining children. Later in this 
review the ramifications of such a situation will be addressed.

The tasks mentioned above are accomplished by three specific steps: 1) the family must prepare to relinquish the memory of the deceased as a force in family activities, 2) the family must realign the intrafamilial roles, filling the vacant ones, and 3 ) the family must realign the extrafamilial roles, including clubs, churches and social groups. ${ }^{3}$ These may or may not be accomplished by conscious efforts on the part of the family, but in either case the effects can be most important for the family. Kaplan, et al, in his study of predicting the impact of severe illness in families, established criteria for rating family coping responses. ${ }^{4}$ This rating system was based upon: 1) the ability of the parents to comprehend the nature of the disease, 2) the ability of the parents to communicate the seriousness of the illness to all members of the immediate family, including the patient, and to relatives and friends, as well, and 3) the ability of the parents to respond to the diagnosis with appropriate feelings of grief and sadness without inhibiting the expression of these feelings in themselves or in any family member. In Kaplan's study family responses were considered adaptive only if they met all three of these criteria. Findings indicated that only $10 \%$ for four of the forty 
families surveyed) made an early adaptive response to the diagnosis of leukemia in one of their children. It was found that substantial differences occurred in the impact of the illness on the survey families in accord with the effectiveness of their initial coping response to the diagnosis. Most families in the study were given poor stress outcome ratings because the data indicated they were still overwhelmed by the situation even three months postmortem. Only 128 came through the experience without suffering serious damage to effective family functioning.

Kaplan makes a strong cáse for extending clinical concern to include families for two reasons: because of the unique role the family plays in mediating stress for all its members and because severe illness often has harmful effects on those members who do not suffer from the disease itself. ${ }^{5}$ Not only does Kaplan recommend clinical services be extended to families, but he is convinced the optimal period for intervention is during the early acute stage of the crisis, immediately following the confirmation of the diagnosis. It is at this time the family is making those decisions associated with maladaptive coping and poor stress outcome. An essential ingredient of mastery over stress in these families is that both parents respond realistically to their new situation with its burdensome demands, sacrifices and 
often gloomy prognosis. Early intervention by medical staff and therapists can assist families in a constructive and realistic approach to their problems.

Confirming the need for immediate intervention with families of seriously ill children, Binger (1969) sites his study of the emotional impact of childhood leukemia on the patient and his family. He found that parents did not feel the actual death of their child was the most vividly remembered event. By the time death occurred they had become somewhat prepared for this to happen. Instead, they most vividly remembered being told the diagnosis and the grief that it initiated. Death, or the threat of death, calls forth many emotions including loss, guilt, anger, a sense of relief, anxiety, a feeling of helplessness, hostility and fear. Some individuals may experience all or only part of these emotions. Binger, et al, found that from the initial diagnosis through the illness of the child and his subsequent death, parents manifested all aspects of anticipatory, as well as subsequent, grief reactions. 6 Included in these were intellectualization, irritability, depression, somatization, denial and frenzied activity. Many factors effect the way in which individual parents react to the stress of having a child with a life-threatening illness. Some parents are overwhelmed by feelings 
of guilt and inadequacy at producing an imperfect child, for example. Even strong fears of a breakdown may persist as the mother or father feels less confident in the role of parent, less able to contain and control the well children at home. Because these feelings may be so overwhelming parents in some families may become caught up in what Turk (1964) called a "web of silence". 7 For fear of losing control altogether they prefer not to speak of the illness unless forced to do so. Gyulay (1975) found that this "web of silence" was detrimental to the family as a whole. ${ }^{8}$. She emphasizes the need for parents to encourage openness and allow participation and questions about the illness from all family members. The family's ability to cope and the sibs' comprehension of the situation depends upon this important ability in the parents. She also advises total family conferences, with the medical staff treating the sick child. In these sessions the family as a whole should have an opportunity to discuss any desires, fears and questions at times of diagnosis, remission, exacerbation, terminal event and postdeath. She laments that this sort of arrangement is all too rare in medical settings today.

The impact of changes in family structure during periods of life-threatening illness, when families antic- 
ipate the death of one of their members, can rebound in complicated ways upon siblings. Through the realignment of the family dynamics the well children may be effected greatly by their parents' new and often confusing behaviors. In fact, Nagera (1970) believes that sibs are influenced far more by the actions of their parents during these stressful periods than by the condition of their ill sibs. ${ }^{9}$ one example she gives is the readjustment necessary when each parent has had a child to care for and nurture. If one of these children's lives is threatened the well child may become caught up in the parents' struggle for possession of him. Goldberg cites the practice of "scapegoating" as another hazard of the family under stress. ${ }^{10}$ He believes parents often feel guilty for any or all of the following reasons: 1) ambivalent relationship with the ill child, 2) previous desire for him to die, 3) feelings of anger at the dying child for leaving, or 4) a wish that more had been given of oneself. The parent can unknowingly transfer these feelings to a well child in the family. According to Goldberg scapegoating serves to relieve and prevent parents from facing guilt. It may take the form of parents finding fault continually, being annoyed at the well child or actively blaming him for the condition of his sick brother or sister. 
Another common coping mechanism Binger found in families of leukemic children was the way in which fathers often absent themselves from the painful involvement with their troubled families. ${ }^{11}$ pleading a heavy work load or the need for a break from it all, fathers find it easier to avoid the increasing problems encountered by a family in crisis than do the mothers. Because traditionally the mother's role has been one of nurturing and because in the past she has usually been freer of breadwinning responsibilities she has been more actively involved in the hospital treatment regimen and care at home. All of which may lead to greater and greater polarization of the parents at a time when their unification and solidarity are of utmost importance to the family.

Kaplan states that in families experiencing adjustment problems to the life-threatening crisis one of the most common causes is that one parent has accepted the diagnosis and prognosis while the other parent denies them. ${ }^{12}$ The parent who accepts the diagnosis and the reality of a life in danger must cope with feelings of grief. When he or she turns for solace to the marriage partner he or she is rebuffed. The partner neither wants to hear nor believe what is being said. While marital problems are often reported in families without lifethreatening crises, these same sorts of problems are 
aggravated in families with an ill member. The divergent reactions of the spouses to the illness are frequently the cause.

While the parents are grappling with these new and confusing adjustments to each other and to the situation they are also experiencing various degrees of personal grief at the prospect of losing a child. Goldberg states that the grief-work necessary for successful adaptation to the life-threatening or death situation consists of three phases. ${ }^{13}$ First, the individual must become emancipated from the bondage to the ill or dead person. Second, he must make preparation or readjust to the environment in which the individual is missing. Third, he must form new relationships to replace the old ones. These phases are accomplished through two major steps: introjection and loosening of ties to the lost object.

Anticipatory mourning and grief work of this nature often makes parents feel depressed and they find, to their distress, a lack or warmth and an irritability towards everybody including their children. Burton has found that parents may be so overwhelmed by the demands made by the illness that they resent demands for attention from the well sibs. 14 Gyulay noted some parents were especially resentful of the well sibs' physical complaints or minor illnesses. 15 She reports remarks such as, "He just had 
another headache and moped around to get attention while his sister was dying." Some parents felt guilty over this resentment and anger, while others maintained their feelings were justified under the circumstances.

Bowlby, in his lecture on childhood mourning and its implications for psychiatry, states that anger is an immediate, common and perhaps invariable response to 1oss. 16 According to Kubler-Ross, anger is an essential phase in grief-work, usually displacing the denial that immediately sets in after the diagnosis. ${ }^{17}$ In fact, Bowlby believes that one of the distinquishing features between normal and pathological mourning is the inability to express overtly the anger one feels over a personal loss of this magnitude. Instead of accepting this anger as normal and necessary to successful adjustment many parents try to conceal it or misplace it. Hospital staff and doctors often receive this displaced anger as the parents struggle with their grief, but the well child at home is particularly vulnerable. Burton states that depending upon the child's particular personality and the meaning he has for the parents he may be the recipient of their initial anger and frustration.

As was pointed out earlier, children are usually far $\checkmark$ more influenced by the behavior of their parents than by the condition of their sick sibs. If the messages well children are receiving from their parents are confusing and erratic they tend to behave in confusing and erratic patterns also. 
To a degree, however, their behavior during these periods of crisis depends upon their understanding and comprehension of death. There is some disagreement in the literature as to the age at which children are able to fully comprehend the concept of death, grasping as well the idea of its finality. Wolf (1958) believes that something similar to the adult comprehension of death is not observed in children before the age of ten or eleven. ${ }^{18}$ Furman (1964), on the other hand, holds the opinion that a two to three year old is capable of mastering the meaning of death and that a three to four year old has the capacity to mourn. 19

The issue of mourning is a controversial one in the area of childhood reactions and grief. While Furman believes the very young can experience true mourning, Wolfstein contends mourning in the Freudian sense can not be experienced until much later. ${ }^{20}$ She believes even in adolescence mourning is a trial period and until one has experienced this period mourning in an adult sense has not taken place. "Mourning as defined by Freud and as observed in the adult is not possible until the detachment from parental figures has taken place in adolescence", states Wolfstein.

Whether or not a child is actually mourning in the adult sense of the word, the death of a close relative is not only a traumatic event, but is a development interference as well. For the adult who is working through the adaptation to a threatened loss everything else is temporarily suspended until 
the mourning process is completed. But according to Nagera the child is not a finished product as is the adult. ${ }^{21}$ He is the process of a multiplicity of developmental steps in all sorts of areas and directions. Mourning or grief-work must take place simultaneously with, and in subordination to, such developmental needs as are appropriate to the age of the child. For this reason children are usually incapable of prolonged and sustained mourning as observed in adults. The most important difference between the child's and the adult's mourning is that the child more likely reacts with anxiety, multiple forms of regression, occassional periods of giving up certain ego achievements and by development of abnormal forms of behavior.

Gyulay believes children's fears are reinforced in our society because we don't express out true feelings when death occurs. 22 Children can't understand why their parents are crying. when. "God is taking care of Danny up in heaven." For this reason she believes it is important to establish a setting where the well children in the family can ask questions, view, strike out, release, touch, describe and act out. According to Gyulay children need the comfort of knowing they are accepted, told the truth and loved through such a painful experience. At the very time the well sibs need so much attention and understanding from the parents, their own behavior is less likely to elicit the needed care. Burton believes that children or all ages view parental preoccupation as a rejection of 
themselves. ${ }^{23}$ As a consequence of parent's absorption in continued crises of, the exigencies of treatment, feelings of jealousy, guilt and resentment, engendered in well children by obvious disparities in handling may cause immediate and acute pain for them. Not only can these feelings contribute to longterm personality defects, but they can cause the children to become less appealing to the parents. The children may suffer actual rejection because of the acting out, withdrawn or labile behavior, the lack of understanding (more projection by adults than reality, depending upon the age of the children), or even the physically healthy state of the well sibs. The emotional and physical absence of the parents can lead to more intense withdrawal or acting out. This can form the basis of a "visious circle" of rejection into which many families fall. After the death, or perhaps even the possible recovery of the ill child, the ties which were loosened with the well children during the period of illness are never really tightened again. The last months and years cannot be relived. According to Burton (1973) sibs will respond to parent's' preoccupation (and in some cases real rejection) in different ways depending upon the age of the child. ${ }^{24}$ In this type of situation the baby is the most vulnerable. Worried about the sick child the mother can adapt less successfully to the baby and 
provide a relaxed awareness of his needs, picking up on his cues and making sense of this environment. The younger the child the more potentially damaing this experience can be because of the urgency of his emotional needs. The possiblity of a change in the infant's development due to such factors has been illustrated by Davidson in his study of mothers and their young children. ${ }^{25}$ He describes a child following his mother into her depression and produces evidence to show that the mother's mood contributed to the infant's emotional pattern. His findings indicate these responses persisted into adult life. This inadequate mother/child interaction is seen as a potential trauma, a very complex process and influenced by many factors. Davidson points out that each stage of development has its potentially vulnerable age. For the older child this may present an even greater problem.' Although the older child may understand the seriousness of the situation he may still feel the parents' concern for the sick child is a rejection of his own needs. He may become resentful and angry at not having his needs met, but feel guilty at the same time for having those needs at all. Often he makes an effort to deny his own needs and can become overly solicitous of his sick sib. Many writers, including Freud (1969) in her paper on the concepts of the rejecting mother, have emphasized 
the ways in which parental preoccupation of any kind limit the mother's perception and ability to respond to the emotional needs of her other children. 26 As a result the whole course of the well child's development may be altered. When the parents sense they are depriving or scapegoating a well child they may try to make amends and experience difficulty in legitimately disciplining all their children. As a result the younger ones become confused, often resorting to aggressive behavior. Older children may become resentful and angry. Frightened of becoming ill themselves they may taunt the sick child or develop psychosomatic symptoms in a bid for reassurance and the required attention.

So common are these reactions in well sibs that Binger, et al (1969) found such difficulties in one or more of the well siblings of half of the leukemic children whom he and co-workers studied. 27 Rosenstein $(1970)^{28}$ noted behavior disorders, resentment and depression among most of the well siblings of cystic children and Blom (1958), even noted jealousy among the siblings of children hospitalized for tonsillectomy. 29

Burton found that these reactions were to some degree dependent upon the age of the well sib in relation to the sick child. 30 If the sick child is the younger child, birth rivalries may be reactivated. If he is the 
older child his younger siblings may become openly jealous. Data also demonstrates that the older well sibs display more positive protective feelings toward their younger sick sibs than if the order is reversed. Older well children are clearly faced with a dilemma in this situation. Although they might resent all the attention which their younger sick sibs receive, they are old enough to appreciate that it is essential. Burton believes they tend to mirror their parents concern for the sick child when demonstrating protective behavior. In some cases the need to do this stems from guilt in the older siblings' past, either because he is well while his brother or sister is ill, or because he has felt resentment about the attention the sib has received. Burton has rarely found overt jealousy in older well sibs. 31 This may be because in comparison to younger children they are more in control of the expression of emotions and can hide negative feelings. Aiso it may be that their guilt, responsibility and worry concerning the sick child may limit open expression of less socially acceptable emotions.

Jealousy, however, is the most frequently encountered response in younger siblings of ill children. These sibs: usually have little or no experience with either personal grief or the grief others are experiencing. Their anger 
and jealousy often stem. from the fantasies they have about the fun and attention their sick sib gets while in the hospital. They can continue to have these fantasies in spite of the obvious pain and exhaustion some of their sibs experience in the hospital. When family and friends are constantly inquiring, "How doés Bobby feel today? What do the doctors say? and when will he come home from the hospital?" it is easy for the well child to believe all the attention is focused on the sick child. He may well believe that to get attention at all one has to be sick.

older children are often very aware of the jealousy their younger brothers or sisters feel, but Burton's data suggests parents rarely feel this kind of jealousy presents a real problem to them or the family as a whole. 32 Despite this lack of parental concern Burton feels it is important for parents to address the issue: Evasive and inadequate communication is thought to be the source of much confusion and jealousy on the part of well younger sibs. This, in general, contributes to overall behavior problems. Burton urges parents to seek help in how to five age-appropriate and anxiety-allaying explanations, especially where no spontaneous queries have occurred about the illness and its ramifications. Kaplan, et al., (1976) also believes honest open 
relations between parents and children may prevent much of the reactive behavior of well sibs. 33 Although they do not necessarily advocate actually "telling" a child his brother or sister is going to die, they do advise that he be kept aware of the serious nature of the illness. If the well sib is unaware that death is a possibility because of the illness he or she may be permanently affected by the obvious discrepancies should the sick child die. "Bobby was supposed to be getting better, but now he is dead. Someone did not tell the truth."

One of the most thorough and most often cited references in the literature on the siblings of ill chldren is the well-known study by cain, et al. ${ }^{3.4}$ Their study on children's disturbed reactions to the death of a sibling is especially important to note in this review because of the interest in siblings' reactive problems. The current literature places great emphasis on the issue of jealousy among well and sick siblings and its ramifications. One current idea is the concept that the primary, if not the exclusive pathological impact of a child's death on his or her siblings is one of guilt over rivalry-bred hostile wishes. Supposedly the well child believes his wishes have been fulfilled by the illness or eventual death of his sibling and he believes he must 
atone for this ghastly deed. Cain believes the serious illness or death of a sibling must be seen as much more than just the production of guilt.

Cain characterizes well siblings with disturbed reactions as often exhibiting depressive witharawal. accident-prone, exhibitionistic and pusnihment-seeking behavior accompanied by constant provocative testing and acting out. Yet he believes more than guilt is responsible for this phenomenon. The deterioration some well sibs experience in their general level of functioning problems as having serious difficulty in fulfilling major roles (especially student in the case of a child) Kaplan found that $43 \%$ of the families he surveyed had at least one well child with school problems. 35

If the realities of a situation such as this leaves the sibling. feeling useless and unwanted, the child typically becomes angry and then fearful of losing control. He often attempts to prove he has no anger at all and so can appear "emotionless". Parents, unaware of the reasons for this reaction, can be disturbed by the child's lack of proper sentiment and "blame" him for his unfeeling reactions.

Another disturbed reaction found by Cain and his co-workers to the serious illness or death of a child was distorted concepts of illness and dèath. Siblings 
often are confused by the relationship between the two. Much depends upon the child's developmental stage of evolving concepts about death. Young children may believe that one only dies when one is very old. When a brother or sister appears to be dying these children must struggle with the obvious contradictions. Cain's data suggest that many confusions about death and illness emerge in childhood. Beliefs such as you die because you are small, you die only at night, you can't die until you are nine years old (age of sib at death), only girls die young or if you get sick at all you have to go to the hospital to die, are common among young sibs. These confusions can lead to innumerable fears on the part of children--fears of the ninth birthday, fear of the dark and especially fears of being "sent away" if one should become sick. Disturbed attitudes about doctors, hospitals and religious beliefs are also common in the well sibs of sick or dying children. Doctors and hospitals can. represent fearful and painful places to any child, but to the child who has stood in the hall and heard a brother or sister have a bone marrow test, hospitals can appear to be torture chambers. The fear of the doctor can be heightened especially if the doctor is unable to relieve the sib's pain or if he is unable to 
successfully combat the illness. This distrust is only increased when parents and relatives are also suspicious, angry or hostile toward the doctors and the other hospital staff.

Religious faith which may have sufficed in the past may also be questioned by children at this point. "If God can make a person so sick he can also make him well. Why doesn't he?" Cain found one child who firmly believed God had taken her brother away, but was göing to "give him back" any day.

According to Rosenblatt some therapists may hesitate to intervene in religious issues of this sort because of the possibility of intruding where they do not belong. ${ }^{36}$ Rosenblatt believes at the time of intervention the therapist must remember the aim of therapy is not to interfere with the religious customs and practices which the family has chosen for itself. Instead, the goal is only to correct distortions, increase the relative power of the reality principle and show the patient those areas of his mental life where unconscious factors are influencing him. The extent to which one would go with this practice would depend upon the age of the patient.

Cain has also discovered strong death phobias in some of the children he and his co-workers surveyed. 37 
An intense fear of death is not uncommon among siblings whose brother or sister is seriously ill or dead. Some children fear they, too, will die, even from a common cold. This fear of death is even more pronounced in children who suffer from the early stages of the same illness or genetic condition as their sibling. Often this phobia is not just a reaction to the illness or death itself, but is in response to the parents! fearful reactions and overprotectiveness. Cain has found that when children are kept from basic growth experiences by parents these children become generally immature, passivedependent individuals who may be fearful and phobic in many areas.

Another reaction to having a seriously sick sibling which is not uncommon is the constant use of comparisons, identifications and misidentifications. Some children compare themselves to the dead or dying sibling and feel they come up lacking in something essential. Parents can contribute to this unknowingly by expecting the well sibling to behave as his sick brother or sister did in the past. Often its a case of the parent or child "misidentifying" and actually believing the well child is just like the sick or dead child. To attempt to follow in the exact footsteps of a dead or dying brother or sister unquestionably leads to serious emotional disturbances 
according to cain.

Disturbances in cognitive functioning, traceable to denial mechànisms, were also found by cain, et al. Some children were found to have cognitive "gaps" or a lack of knowledge in specific areas. While they were otherwise intellectually intact these gaps appeared especially in the areas of time concepts and causality. As pointed out earliest Cain believes his data indicates the impact of the serious illness or death of a sibling is far more than just a question of rivalry and jealousy. He has found that children are involved in such areas as affect, cognition, belief systems, superego functioning and object relationships. The degree to which each child is affected is influenced by many factors including: 1) the degree of actual involvement with the sick sibling and his routine, 2) the child's pre-existing relationship with the sick sibling, 3) the impact of the illness on parents, 4) the impact on the family structure, and 5) the developmental level of the child at the time of the sibiling's illness.

As this review has shown there are many possible responses to the serious illness of a child's sibling. Some of these are part of a normal and even necessary process through which a child must go to successfully adapt to a traumatic situation. Some of them are not 
normal nor adaptive responses and can seriously hinder a child's acceptance of the situation, even his fundamental development. Not only does this present problems to the individual child, but the family as a unit also suffers when the functioning of any of its members is impaired. Despite the serious effect these factors can have upon the family, as well as the patient or ill child, it is not surprising that in the past medical personnel, more specifically doctors and nurses, did not pursue the issue more thoroughly. Burton contends that doctors and nurses often view death or the immediate threat of death, as a professional or even personal failure. ${ }^{38}$ This along with their own fears of death may have contributed to their inhibitions about inquiring into the repercussions the illness may have on people other than the immediate patient.

The current literature; however, indicates not only an interest in the family during this period of crisis, but also a general concensus, in that intervention should begin as soon as possible after the diagnosis of a life-threatening illness is made. Studies of the concept of crisis suggest that both individual and family reactions to such threats as prolonged or fatal illness are fashioned from one to four weeks after the diagnosis is confirmed. 39 During these first few weeks coping 
patterns are not as fixed as they become in time. Even though the coping demands for any serious illness are not static (but change as the medical treatment changes), the coping patterns are likely to become more rigid after the first month or so. Therefore the ideal time to discover maladaptive patterns and intervene is during this early phase.

Some therapists have even suggested that wide-spread preventive treatment for emotional desturbances due to loss through death could be initiated in families prior to any diagnosis of serious illness. Rosenblatt, however, finds the suggestion of preventing psychopathology due to death on any large scale not only fruitless, but ridiculous. 40 "If we wish to prevent children from developing emotional illnesses as a consequence of losing loved ones in death, we shall have to do away with death itself." Instead, he recommends a program of therapy beginning after diagnosis and designed for the specific needs of childhood sibling loss.

Kaplan, et al., believes it is possible to develop "preventive" or clinical programs which are capable of reversing maladaptive coping responses in children due to the illness of a sibling. 41 He emphasizes, though, the success of these programs is contingent on having detailed knowledge of the process of adaptation specific 
to each illness, including relevant coping tasks and methods of task accomplishment.

Feinberg developed a specific method of treatment for disturbances from childhood sibling loss. ${ }^{42}$ He worked for over an eight-month pre-death and two-month post-mortem period with two sisters of a young boy dying of leukemia. He lists five important parts to this treatment: 1) an immediate and persistent attempt by the therapist to establish a therapeutic alliance based on forthrightness, 2) the stimulation and encouragement of "immunizing" discussions, 3) the encouragement and allowance of catharsis without severe regression, 4) emphasis on reality orientation and.5) direct initiation and enhancement of mourning using transference material wherever possible. Each of these treatment segments plays an important part in successful therapy.

Forthrightness: When working with sibiings the questions of just how sick is my brother and what is going to happen to him often arise. Difficulty in resolving the question of whether or not to tell the child always contributes to poor handling of the case. Feinberg suggestsa method of readiness to tell the truth while the task of the child is to ask. A readiness to tell the truth helps establish an emotional climate of trust between a therapist and child, a climate in which unpleasant 
information can be shared.

Immunizing Discussions: Theoretically a primary

object loss can be more easily experienced in a displaced fashion such as previous deaths of pets or of people outside the primary family. With some children these discussions occur spontaneously, but if it doesn't Feinburg advises persistent evocation of such a process. He believes this will achieve a more intense and frequent reworking of affects.

Allowance for Catharsis: Secondary to the immediate concerns of permanent separation and loss aroused by a sibling's dying, is the shift of attention by the parents to the sick child. This always causes anger and resentment. If this is not dealt with with aggressive and subsequent guilt or regressive yearnings for the unavailable parents lead to symptoms or acting out. Feinberg states that therapy should allow for as full a catharsis as possible. Catharsis is a constructive ego experience because therapy not only allows for communication of feelings, but encourages a child to "stay with" feelings over an extended period of time. Catharsis with very little interpretation can lead to a better choice of defenses.

Reality Orientation: This phase involves the initiation and carrying out of mourning. Conscious efforts by the therapist to detail the course of pathology of an 
illness, the child's perception of the parents' clinical symptoms, as well as an orientation to the correct chronology of the upsetting events surrounding it, should contribute to a more reality-oriented attitude toward death itself. In essence, the child needs more understanding of the emotional responses of others and Feinberg believes the therapist has an opportunity to promote this understanding.

Initiation of Mourning: The aim of treatment work should include remembering of the lost object whether the memories are sad or happy. Feinberg believes that through the use of transference manifestations of feelings of loss and separation spontaneous remembering can be facilitated in children. Kliman (1968) is in agreement with Feinberg in that he feels what is sufficient to allow a healthy child to mourn is an opportunity to be helped in a supportive and encouraging way to aradually express his feelings. ${ }^{43}$ The frequent introduction of sadness at appropriate times, as well as the sharing of it with an adult ego in a way that makes it more tolerable, has an importance to the child's psychic economy. According to Kliman the gradual liberation of anger and sadness prevents untoward defenses against them. 


\section{SUMMARY}

A review of the literature has revealed several significant facts about childhood sibling illness or loss. Although there is some disagreement about the age at which children comprehend death and whether they actually mourn or not, researchers are in agreement about the significant impact the death or severe illness of any family member can have for children. Members of a family do not act and react independently of one another. What affects one usually affects all to some degree. For several reasons death presents a special crisis for families. Immediate professional intervention is indicated for families facing death in order to assist in establishing adaptive coping mechanisms.

Data has shown that children may be more influenced by the way in which parents cope and react to crisis than by the condition of their sick sibling. When parents are concerned and preoccupied with their sick child they are unable to give as much attention as they did previously to their well children. Children interpret this lack of attention as rejection. Jealousy on the part of younger children and anger and resentment in older siblings are common responses.

Disturbed reactions are also a response to childhood 
sibling illness or loss. Distorted concepts of illness and death often develop if there is a lack of communication about the illness and its progression. Hospital, doctor or religious phobias are also possible when children cannot find logical explanations for the events occurring in their lives. Even strong death phobias can develop in children facing the fearful complexities of sibling 1oss.

While most authors feel early intervention is essential, there is disagreement about large-spread preventive therapy before any diagnosis of a life-threatening illness has been made. Some authors feel it could be of benefit, while others feel it is a fruitless proposition. Once a child is engaged in therapy, however, there are specific steps therapists can follow which may enable the child to discard maladaptive defenses and to develop more appropriate ones. The basis of this therapy is an open, honest, supportive environment where a child can ask, remember, discover and recover. 
CHAPTER II-NOTES

1. S.B. Goldberg, "Family Tasks and Reactions in the Crisis of Death", Social Casework, Vol. 54 , no. 7 (July, 1973), pp. 398-405.

2. Ibid.

3. Ibid.

4. David M. Kaplan, Rose Grobstein and Aaron Smith, "Predicting the Impact of Severe Illness in Families", Health and Social Work, Vol. 1, no. 3 (August, 1976), pp. 472-481.

5. Ibid.

6. C.M. Binger, "Childhood Leukemia: Emotional Impact on Patient and Family", New England Journal of Medicine, (February 20; 1969), pp.414-417.

7. Ibid.

8. Jo-Ellen Gyulay, "The Forgotten Grievers", American Journal of Nursing, Vol: 75 (9), ( September, 1975), pp. 1476-1679.

9. Humberto Nagera, "Children's Reactions to the Death of Important Objects", The Psychoanalytic Study of The Child, Vol. XXV, International University Press, Inc. New York, 1970.

10. Goldberg, op.cit.

11. Binger, op.cit.

12. Kaplan, op.cit.

13. Goldberg, op.cit.

14. Iindy Burton, The Family Iife of Sick Children: A study of Families Coping With Chronic Childhood Disease, Routledge and Degan paul It. Boston, Mass. 1975.

15. Gyulay, op.cit.

16. John Bowlby, Childhood Mourning and Its Implications for Psychiatry, Macmillan, New York, 1973. 
17. Elizabeth Kubler-Ross, on Death and Dying, New York, Macmillan, 1969.

18. Albert C. Cain, I. Fast, and Mary E. Erickson, "Childhood Reactions to the Death of a Sibling", American Journal of Orthopsychiatry, Vol. 34, pp. 741-752.

19. Ibid.

20. Ibid.

21. Nagera, op.cit.

22 Gyulay, op.cit.

23. Burton, op.cit.

24. Ibid.

25. John Davidson, "Infantile Depression in a Normal Child", Journal of the American Academy of Child Psychiatry, Vol. 7, pp. 522-528.

26. Anna Freud, "The Concept of the Rejecting Mother", in Indications for Child Analysis and Other Papers, Hogarth Press, London, 1969.

27. Binger, op.cit.

28. S.I. Harrison, C.W. Davenport and J.F. McDermott, "Children's Reaction To Bereavement", Archives of General Psychiatry, Vol. 17, pp. 593-598.

29. Ibid.

30. Burton, op.cit.

31. Ibid.

32. Ibid.

33. Kaplan, op.cit.

34. Cain, op.cit.

35. Kaplan, op.cit.

36. Bernard Rosenblatt, "A Young Boy's Reaction to His Sister's Death", Journal of the American Academy of Child Psychiatry, Vol. 9, pp. 321-325. 
37. Cain, op.cit.

38. Burton, op.cit.

39. Kaplan, op.cit.

40. Rosenblatt, op.cit.

41. Kaplan, op.cit.

42. Daniel Feinberg, "Preventive Therapy with Siblings of A Dying Child", Journal of the American Academy of Child Psychiatry, Vol. 9, pp. 664-669.

43. Vridna Knapp and Howard Hanses, "Helping the Parents of Children with Leukemia", Social Work, Vol. 18, no. 4 (July, 1973), pp. 70-75: 


\section{CHAPTER III}

\section{METHOD OF INQUIRY}

The specific instrument designed for this study was a questionnaire consisting of thirty-three questions. (See appendix B) The questions in the study were designed to evaluate the interaction between the parents of a seriously sick child and his or her siblings.

The first set of questions covered demographic information including age, sex, number of brothers and sisters and their ages. The second area of question concerned how each child was told about his sibling's serious illness. It was felt that not only were communication patterns established at this crucial period, but that an indication of interaction patterns could be gained by knowing who told the child and how much information was given initially. The third section covered how specific areas of family and individual Iife had changed since the diagnosis of the illness. The fourth and final section centered around the child's perception of the family's (and each individual's) selfimage.

The questionnaire was designed to be administered to the well siblings of seriously ill children. It was also administered to the parents of each well child. 
They were instructed to answer one questionnaire per well child and to answer the questions as they felt their child would. It was felt this would give some indication of how close the family's perception of events were, as well as how well the parents were "reading" their children's reactions. In some cases both parents answered the questionnaire together, in others only one parent was home at the time of the interview.

When designing this study two specific questions concerning the eligibility of participants had to be clarified before it could actually be administered. First, the definition of a child with a serious illness had to be established. Serious illness was considered to be any illness with a life-threatening diagnosis. Although the majority (11) of sick siblings turned out to have some form of cancer (the remaining one had a rare genetic metabolic disorder), participation in the study was originally limited only by the term "serious illness".

Second, it was decided the well child participants would be limited to those between the ages of six and eighteen. This was done to narrow the study to children most likely still living at home and involved in the daily routine. Also, it would insure a certain level of comprehension on the part of the youngest participants. The age of the parents was not limited for purposes of 
participation.

The population for this study consisted of twelve families. Each family had a child (of unspecified age) with the diagnosis of a life-threatening illness and at least one sibling between the ages of six and eighteen. Two families had two well siblings within the specific age range to make a total of 14 child participants and 14 adult-answered questionnaires.

The Majority of these families (10) were drawn from a pool consisting of patients seen by Dr. Robert Neerhout in the Hematology/Oncology unit of the Division of Pediatrics, University of Oregon Health Sciences center. The remaining four families were located by "word-of-mouth" through members of the Candlelighters organization, a group founded by and for the families of children with cancer. One family was being seen for medical treatment in the Metabolic Follow-Up Clinic, Child Development and Rehabilitation Center, Crippled Children's Division and the other three families were treated at other Portland area hospitals. Each of the first eight families was originally approached by Dr. Neerhout. He briefly explained the purpose and intent of the study. If the family was interested in participating in the study I arranged a brief interview, usually at the time of an appointment in 
the clinic. One of the parents, in these cases always the mother, listened to my explanation of the study, reviewed the questionnaire and consent form (see appendix A) and decided upon her family's participation.

The remaining four families were originally contacted by members of the first ten families who belonged to Candlelighters. If they were interested in the program I contacted them on the phone. In order to save time a brief initial interview was not arranged. Instead, the information was thoroughly reviewed on the phone and the families decided upon participation in the study at that time.

of the twelve families surveyed arrangements could be made with only ten for personal home visits to complete the questionnaires. In order to preserve the privacy of the children the parents were asked to fill out the questionnaires in a separate room. The interviewer remained with the children, offering assistance for those who had questions about the survey.

Two families were going to be out of town and could not make arrangements for personal appointments. Interviews were mailed to these families. All of the families contacted decided to participate in the study and no one withdrew after beginning the questionnaire. 
CHAPTER IV

PRESENTATION OF DATA

Throughout the presentation of this data two groups of subjects will be represented in the tables. When a table refers to "sibling" it will always mean the well child who filled out the questionnaire. (If another child is mentioned he or she will be identified as the ill or sick sibling.) When the Word "parent" appears in the tables it will refer to the parent of the well child who also filled out a questionnaire. It is important to note that parents were asked to answer the questions as they felt their well child would respond to them and not as they as individuals would reply to them.

The demographic data for the siblings of seriously ill children is contained in Table I (p. 43). The population for this study consisted of fourteen children between the ages of six and eighteen years from twelve families. The parents of these children also participated in the survey. In three families the fathers were not present (either because of divorce or a prior appointment) and in one family the mother was not present to fill out the questionnaire.

Among the children were seven males and seven females with a mean age of 10.57 years, a median of 9 years and a 
mode of 9 years. These children had a total of eleven brothers and seventeen sisters with only one ill child per family. The age range of the ill children was 3 to 19 years of age with a mean of 7.43 , a median of 6.5 and a mode of 7 and 4 .

Three of the siblings (subjects 4,11 , and 12 ) were younger than the ill child in the family. This is an important fact to keep in mind when analyzing the data on parents' treatment of all children (Table XV) and personal feeling states (Table XIII).

The second section of the questionnaire began with a question about how long had the subject known of his or her sibling's illness. Four of the siblings had known for three months. Six of the subjects in both the sibling and the parent catagories indicated the child had known for six months. Two of the siblings had known for one year. One parent indicated the child had known for onw year. Two siblings responded as "don't know", as did one set of parents. 
TABLE I

DEMOGRAPHIC DATA CONCERNING SIBS OF SERIOUSLY ILL CHILDREN

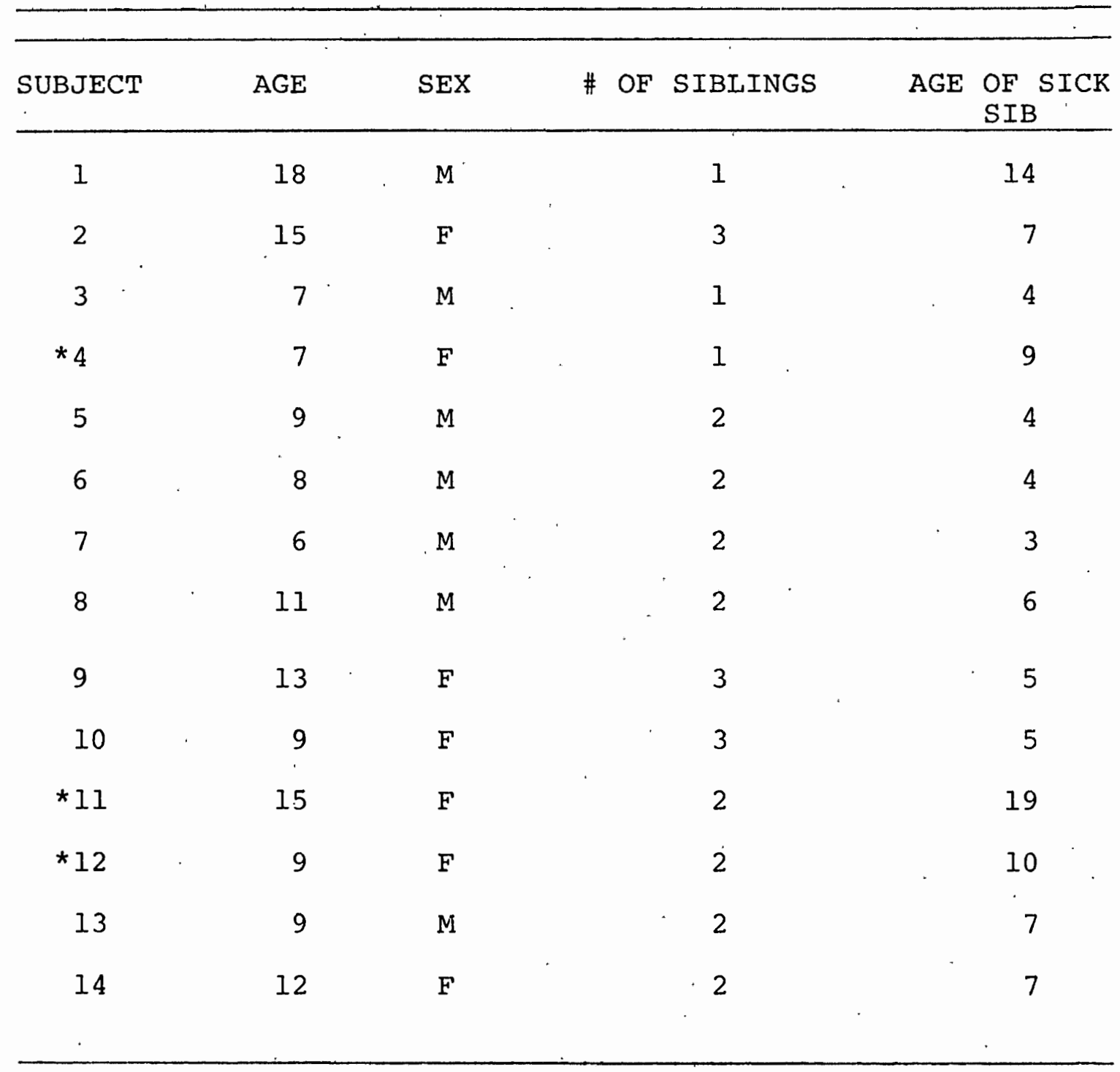

* subject younger than sibling 
TABLE II

WHO FIRST TOLD CHILD OF SIBLING'S ILLNESS

INFORMANT

\begin{tabular}{|c|c|c|c|c|c|c|}
\hline & . & MOTHER & FATHER & $\begin{array}{c}\text { MOTHER } \\
\& \\
\text { FATHER }\end{array}$ & $\begin{array}{l}\text { FAMILY } \\
\text { MEMBER }\end{array}$ & $\begin{array}{c}\text { NO } \\
\text { RESPONSE }\end{array}$ \\
\hline$S$ & SIBLINGS & 8 & 1 & 4 & 1 & 0 \\
\hline$C$ & PARENTS & 5 & 1 & 5 & 1 & 2 \\
\hline
\end{tabular}

Table II indicates how closely the siblings and parents responded to many of the questions. The majority (8) of siblings indicated their "mothers alone" relayed the diagnosis of serious illness to them, with the "mother/ father" category as the second highest (4) response. The parents also rated the "mother alone" category highly (5), but of equal standing with the "mother/father" selection (5). Siblings and parents were in agreement about the number of "fathers alons" who told the child (I) and the number of "other family members" who fulfilled this task (1). Two parents did not respond. 
TABLE III

DESIRE TO KNOW OF SICK SIBLING'S ILLNESS

DESIRE TO KNOW

\begin{tabular}{|c|c|c|c|c|}
\hline$S_{0}$ & YES & No & SORT OF & $\begin{array}{c}\text { NO } \\
\text { RESPONSE }\end{array}$ \\
\hline SIBLINGS & 13 & 0 & 1 & 0 \\
\hline PARENTS & 12 & 0 & 0 & 2 \\
\hline
\end{tabular}

Table. III presents the data gathered in response to an inquiry about the sibling's desire to know of the brother or sister's serious illness. It was believed this information would indicate an early reaction of the siblings to the crisis and their desire to be involved in an uncomfortable situation. The parents'and siblings' responses reflect very similar answers. Thirteen siblings indicated they did want to know of the diagnosis. One sibling did not mark either of the responses provided (yes or no), but, instead wrote in "sort of". Twelve parents responded affirmatively to the inquiry and two parents did not respond to this question at all. 
TABLE IV

LENGTH OF TIME BEFORE SIBS WERE TOLD OF DIAGNOSIS

TIME

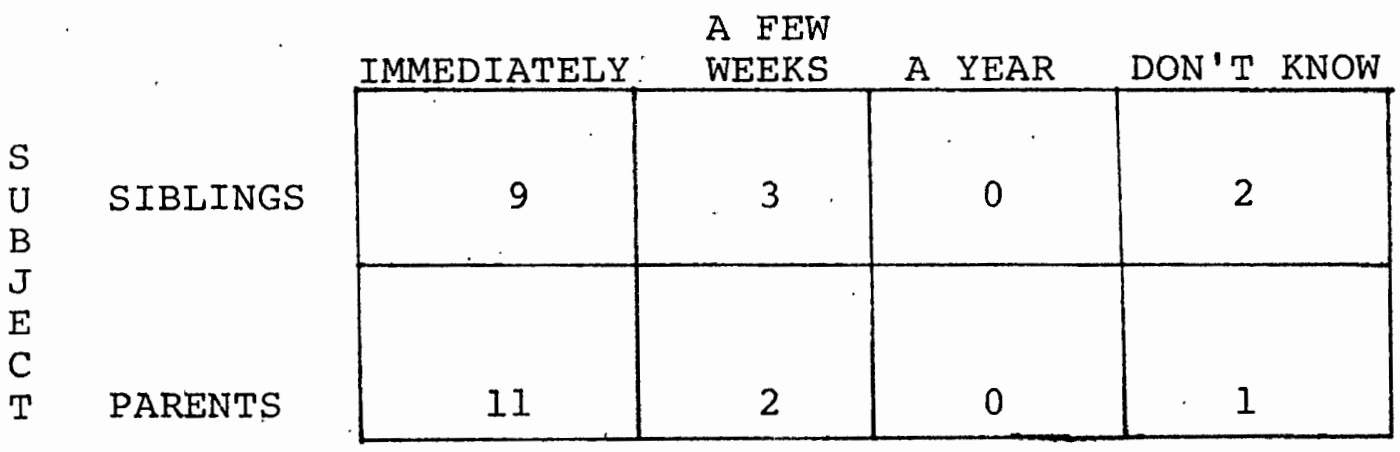

Table IV reflects the responses given to an inquiry about the length of time before the siblings were told of the diagnosis. While an earlier question involving length of time the siblings had known referred to the period of time since they had been told, this question referred to the period of time that elapsed from when the parents were told the diagnosis until the siblings were told. The data gathered at this point would provide information about the skilis and patterns the parents established early in the coping process. Nine of the siblings felt they had been told immediately, three believed they were told within a few weeks and two replied they did not know when they were told in relation to the diagnosis being made. Eleven parents responded with an answer of "immediately", two 
replied "a few weeks" and one did not know how long it had been between the diagnosis and telling siblings.

TABLE V

FREQUENCY OF FAMILY DISCUSSIONS ABOUT CHILD'S ILLNESS

FREQUENCY

\begin{tabular}{ll|c|c|c|} 
& & NEVER & SOMETIMES & \multicolumn{1}{c|}{ FREQUENTLY } \\
S & SIBLINGS & 1 & 13 & 0 \\
$\mathrm{U}$ & & & \\
$\mathrm{J}$ & & & \\
$\mathrm{E}$ & $\mathrm{C}$ & & \\
$\mathrm{T}$ & PARENTS & & & 1 \\
\hline
\end{tabular}

Table $\mathrm{V}$ once again indicates the similarity of replies found so often between the siblings and parents. In response to a question concerning the frequency of family discussions about the sick child's illness, the majority of parents and siblings replied they had these discussions "sometimes". One child indicated the family "never" discussed the illness and one parent believed the family discussed it "frequently". This question was designed to elicit information about family conversation patterns in relation to the illness. Had the child's illness taken priority over all other topics and become the center of discussions? Had the family silently agreed not to mention the problem at all? Or had the family 
accepted the diagnosis and the necessary changes, according the topic an appropriate portion of the daily routine?

TABLE VI

DESIRE TO TALK ABOUT SICK SIB'S ILLNESS

\section{DESIRE}

ABOUT NO

MORE LESS THE SAME RESPONSE

\begin{tabular}{ll|l|l|l|l|}
\hline S & SIBLINGS & 2 & 4 & 8 & 0 \\
$\mathrm{U}$ & & & & \\
$\mathrm{J}$ & & & & & \\
$\mathrm{E}$ & $\mathrm{C}$ & & & \\
$\mathrm{T}$ & PARENTS & & 1 & 10 & 1 \\
\hline
\end{tabular}

Table VI addresses the issue of the sibling's desire to talk about his sick brother or sisters. Depending upon the communication patterns established by each individual family and the level of involvement desired by each child, it was believed the siblings might feel a need for more discussions about the illness and its ramifications. However, they might need less confrontation with the issues involved. if they found it too much to comprehend all at once. The majority of both parents and siblings were satisfied with the present situation. Eight siblings and ten parents wanted the amount of time spent in discussions about the illness to remain "about the same". Two siblings wanted more time for talking and four wanted less time. Two of the parents also wanted more time alloted for discussing the illness and only 
one wanted less. One parent failed to respond to this question.

TABLE VII

CHANGE IN SIB'S RESPONSIBILITIES SINCE DIAGNOSIS

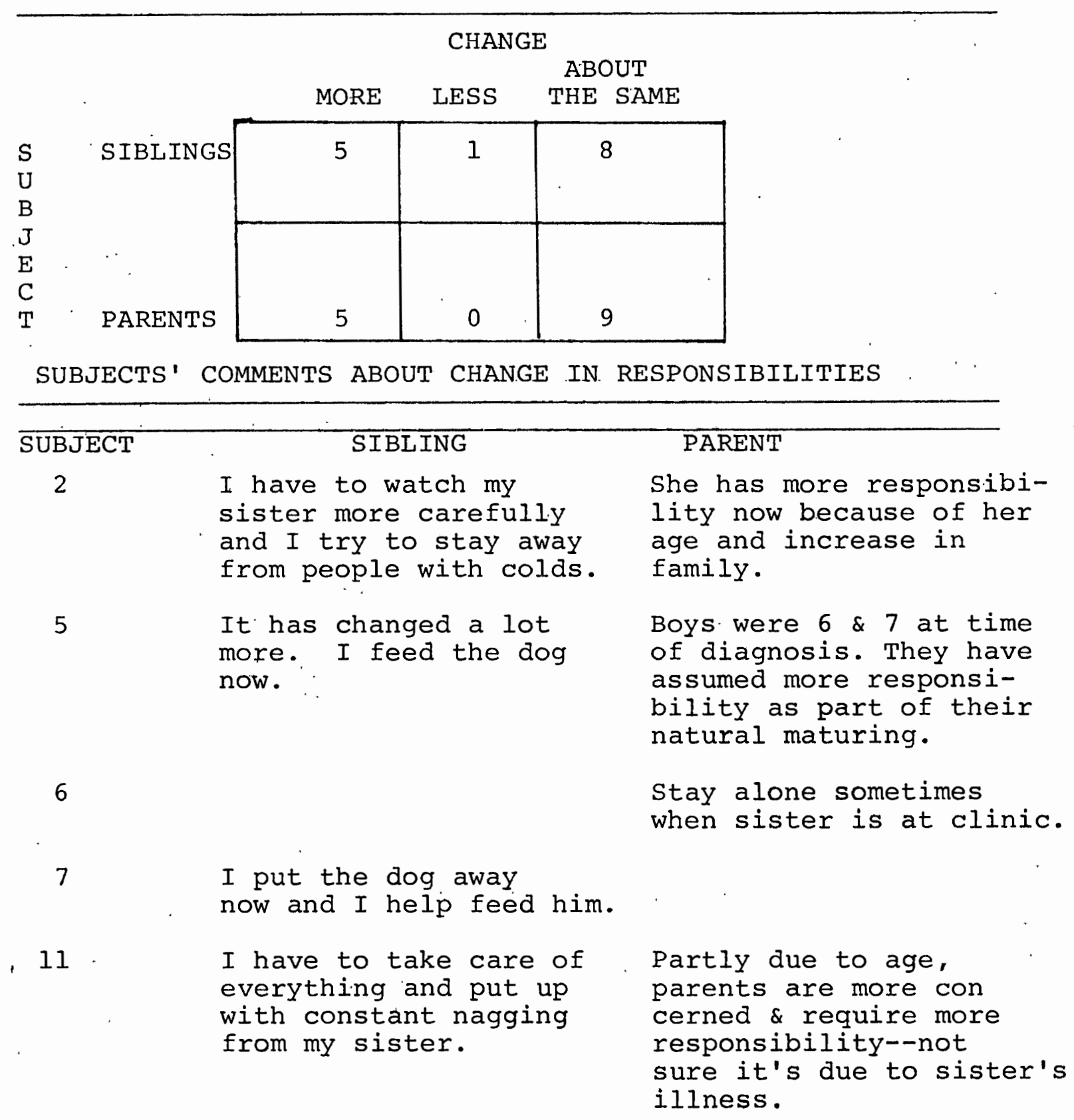


she'd answer less, but she has not teased her sister about her sickness nor about her hair falling out. This must take concentrated effort because she teases her about everything else.

Table VII ( $p .47$ ) presents the data gathered in response to an inquiry about the changes in responsibility experienced by the siblings since the diagnosis of a serious illness. The parents' answers are very similar to those of the siblings. Both the parents and the siblings believed the siblings had more responsibility. Eight siblings and nine parents believed the level of responsibility had remained the same since the diagnosis. It is interesting to note that of the five sets of parents who offered comments about this particular question, three felt the increase in responsibility was related to factors other than the sick child's illness. Maturation and increase in size of family were offered as alternative reasons for change in responsibility.

Table VIII (p.49) depicts the data concerning the change in the sibling's school life since the diagnosis. Seven parents and seven siblings felt no significant change in school life had occurred in relation to the brother or sister's illness. Seven parents also indicated that a "little" change had occurred, while five siblings responded a "little". One sibling replied that school 
had changed "a lot" and one indicated it had changed "completely". It is important to note that the family of these last two children had moved soon after the diagnosis was made and the children had changed schools.

TABLE VIII

CHANGE IN SIB'S SCHOOI LIFE SINCE DIAGNOSIS

\section{CHANGE}

\begin{tabular}{|c|c|c|c|c|c|}
\hline & & NONE & LITTLE & A LOT & COMPLETELY \\
\hline $\begin{array}{l}S \\
U \\
B\end{array}$ & SIBLINGS & 7 & 5 & 1 & 1 \\
\hline $\begin{array}{l}J \\
E \\
C\end{array}$ & & & & & \\
\hline $\mathrm{T}$ & PARENTS & 7 & 7 & 0 & 0 \\
\hline
\end{tabular}

SUBJECTS' COMMENTS ABOUT CHANGE IN SCHOOL LIFE

\begin{tabular}{|c|c|c|}
\hline SUBJECT & SIBIING & PARENT \\
\hline 5 & & $\begin{array}{l}\text { When little sister goes } \\
\text { to school she gets more } \\
\text { than normal attention } \\
\text { sometimes because teacher } \\
\text { are aware of her illness. }\end{array}$ \\
\hline 6 & $\begin{array}{l}\text { Friends talk to me at } \\
\text { school about it. }\end{array}$ & \\
\hline 7 & $\begin{array}{l}\text { We talk about my sister } \\
\text { at school. }\end{array}$ & . \\
\hline 8 & $\begin{array}{l}\text { Some kids say my brother } \\
\text { will give them leukemia. }\end{array}$ & \\
\hline 11 & $\begin{array}{l}\text { It has helped me under- } \\
\text { stand why some people } \\
\text { are different. }\end{array}$ & $\begin{array}{l}\text { Age again--she seems to } \\
\text { want to change and re- } \\
\text { establish her image-- } \\
\text { stronger and independent. }\end{array}$ \\
\hline
\end{tabular}


14 Everyone asks me about her and wants to know about it. They usually come to me or if I'm worried at school I pray about it with a teacher.

TABLE IX

FREQUENCY OF VISITS WITH FRIENDS SINCE DIAGNOSIS FREQUENCY

\begin{tabular}{|c|c|c|c|c|}
\hline & & MORE & LESS & SAME \\
\hline & & THAN BEFORE & THAN BEFORE & AS BEFORE \\
\hline S & SIBLINGS & 0 & 2 & 12 \\
\hline U & & & & \\
\hline $\begin{array}{l}D \\
\mathrm{~J}\end{array}$ & & & & \\
\hline $\mathrm{E}$ & & & & \\
\hline C & & & & \\
\hline $\mathrm{T}$ & PARENTS & 0 & 0 & 14 \\
\hline
\end{tabular}

The frequency of visits the siblings have with friends since the diagnosis is addressed in Table IX. All fourteen parents believed this particular occurrence had remained the same since the diagnosis. However, only twelve siblings felt it had remained about the same, while two believed they visited with their friends less often than before the diagnosis. No one in either catagory believed the number of visits with friends had increased. The information gathered by this inquiry could indicate whether or not the changes experienced by the sibling since the diagnosis have extended beyond the home and school life to encompass activity outside these two important environments. 
TABLE X

DESIRE TO HELP CARE FOR SICK SIB

DESIRE

\begin{tabular}{|c|c|c|}
\hline & YES & NO \\
\hline $\begin{array}{ll}S & \text { SIBLINGS } \\
\mathrm{U} & \\
\mathrm{B} & \end{array}$ & 13 & 1 \\
\hline $\begin{array}{ll}J & \\
E & \\
C & \text { PARENTS } \\
T & \end{array}$ & 11 & 3 \\
\hline
\end{tabular}

Table $\mathrm{X}$ presents data concerning the siblings' desire to actually help care for their sick brother or sister during periods of severe illness. The data gathered at this point could reveal the child's level of involvement in the crisis and his method of coping with stress. Thirteen of the siblings answered affirmatively and one negatively to this question. Eleven parents responded "yes" to the inquiry, while three indicated their children did not want to help care for the sick child. Some parents felt they needed to explain that the sick child never really appeared sick physically, so it wasn't necessary for the siblings to help care for the child. 
PARENTS' TREATMENT OF ALU CHILDREN SINCE DIAGNOSIS

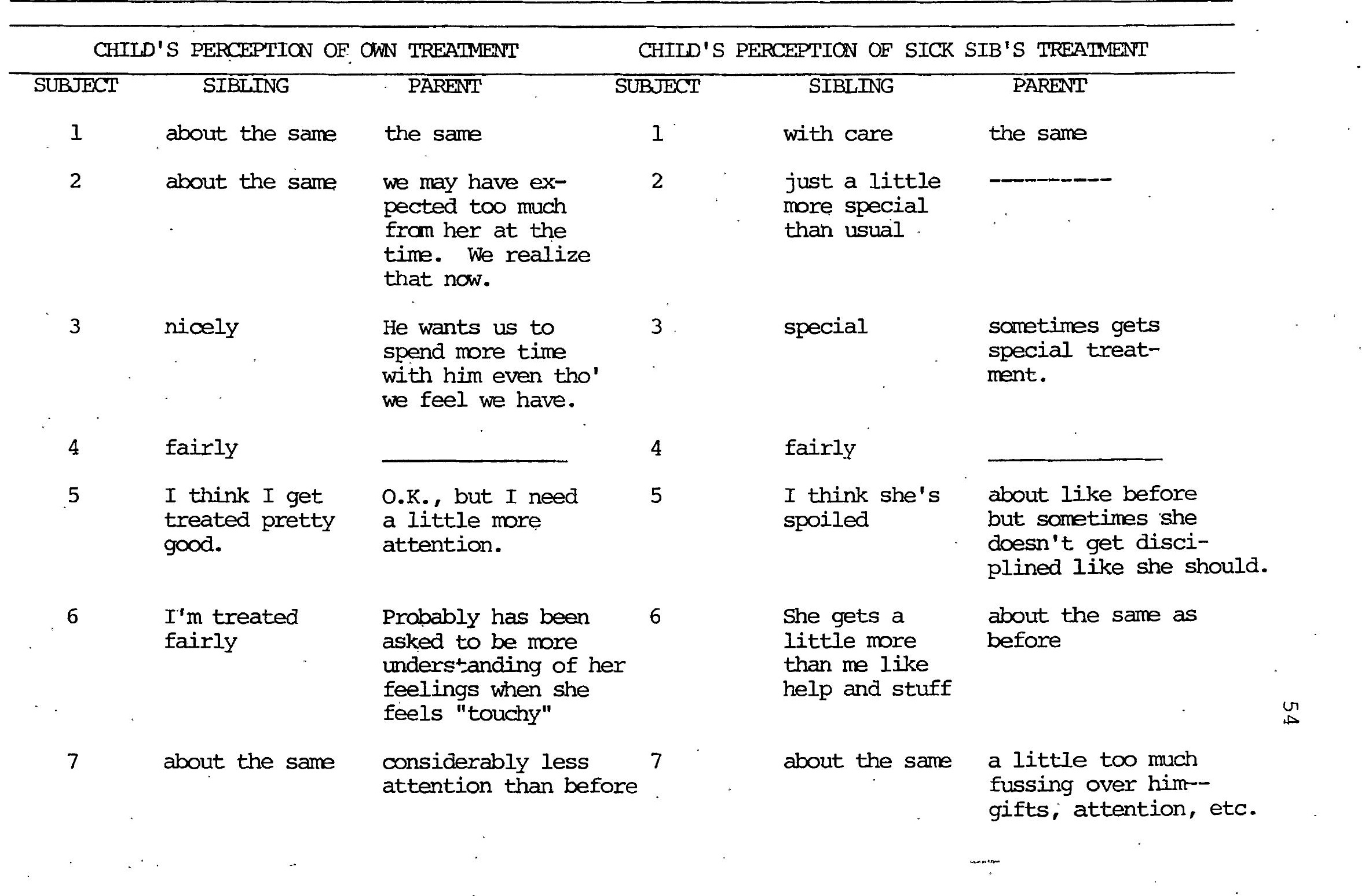




\begin{tabular}{|c|c|c|c|c|c|}
\hline 8 & the same & & 8 & about the same & about the same \\
\hline 9 & about the same & more grown up & 9 & about the same & $\begin{array}{l}\text { they don't scold } \\
\text { him as much }\end{array}$ \\
\hline 10 & the same & same & 10 & the same & not as strict on him \\
\hline 11 & $\begin{array}{l}\text { Not as well as } \\
\text { before. My par- } \\
\text { ents have spoil- } \\
\text { ed my sister. }\end{array}$ & $\begin{array}{l}\text { not enough per- } \\
\text { sonal attention } \\
\text { as she desires, } \\
\text { respect for } \\
\text { individual }\end{array}$ & 11 & $\begin{array}{l}\text { spoiled rotten, } \\
\text { but only for } \\
\text { the first } 2 \text { or } \\
3 \text { years. She } \\
\text { has gotten mean } \\
\text { and hard. }\end{array}$ & $\begin{array}{l}\text { more than her full } \\
\text { share of attention } \\
\text { and respect }\end{array}$ \\
\hline 12 & about the same & $\begin{array}{l}\text { She has said, } \\
\text { "I would Iike } \\
\text { to get all of } \\
\text { the attention } \\
\text { and presents." }\end{array}$ & 12 & $\begin{array}{l}\text { she is treated } \\
\text { fairly }\end{array}$ & $\begin{array}{l}\text { she has got a lot of } \\
\text { nice things at the } \\
\text { hospital }\end{array}$ \\
\hline 13 & $\begin{array}{l}\text { I think pretty. } \\
\text { o.k. }\end{array}$ & $\begin{array}{l}\text { probably not } \\
\text { as much attention }\end{array}$ & 13 & o.k. & more attention \\
\hline 14 & $\begin{array}{l}\text { I'm not noticed } \\
\text { as much, but I } \\
\text { understand. }\end{array}$ & less attention & 14 & $\begin{array}{l}\text { She's gotten } \\
\text { more attention } \\
\text { and more comfort } \\
\text { and sympathy, } \\
\text { but she could } \\
\text { use it }\end{array}$ & more attention \\
\hline
\end{tabular}


Table XI (pp. 54-55) consists of information gathered by two separate questions on the survey. One inquired about the child's perception of his treatment by his parents since the diagnosis. The other question referred to the child's perception of his sick brother or sister's treatment by the parents since the diagnosis. The question was open-ended and the subjects were allowed to fill in the blank space without prearranged responses from which to choose. In response to the first question the majority of siblings replied in a positive manner. Twelve of them felt their treatment had remained the same or was fair since the diagnosis. One child felt she was not noticed as much, but indicated she "understood". the reason for this. Only one child felt she was not treated as well as she had been before the diagnosis. (This is interesting to note in light of the fact that three siblings were younger than the sick child. According to the literature these three should have shown greater jealousy and felt more deprived than the other siblings.) Seven parents felt their child would indicate they. needed more attention, two believed the child would feel he was treated the same, one parent felt the child was treated in a "more grown-up" manner, two felt they had "expected too much" and two did not respond.

In response to the second question about the sick 
child's treatment, five siblings believed their sick brother or sister received special treatment and got more attention than they did. Two felt their sick sibling was spoiled by their parents. In comparison to their own treatment, it appears many of them felt their own treatment remained the same while their sick sibling's treatment changed. However, four children believed the sibling's treatment remained the same and three described the sibling's treatment as "fair" or "o.k." The majority of the parents felt the siblings would believe their sick brother or sister got special treatment. Nine parents replied that the sick sibling got more attention or special treatment, three parents believed the treatment had remained the same and two parents did not respond to this question. 
TABLE XII

AMOUNT OF TIME FAMILY SPENDS TOGETHER SINCE DIAGNOSIS

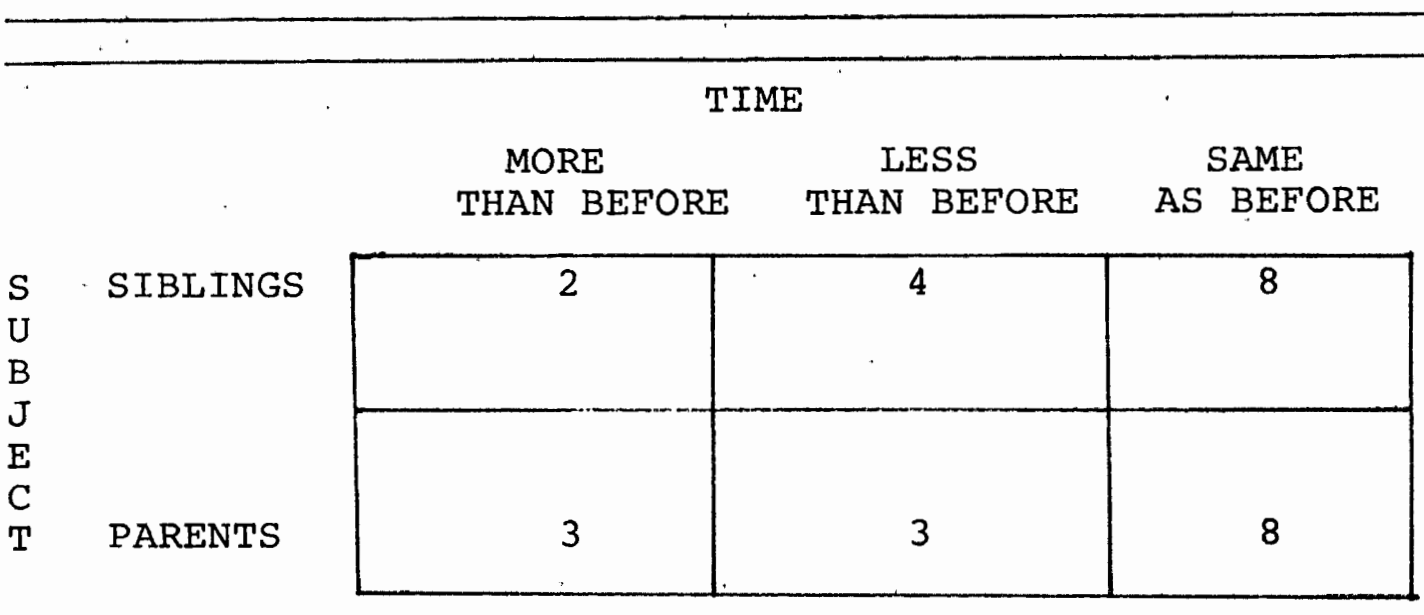

SUBJECTS' BRIEF COMMENTS ABOUT TIME SPENT TOGETHER

\section{SUBJECT \\ 2 \\ 4 \\ because of the one fact that she may not be here some day we spend more time together \\ Mom and dad have to spend time with my sister when she is sick}

7

11

12

14

They still love us, but because of hospital visits and stays

less travel, different interests, less family gatherings

she would say the same, but it is more because my husband and I have certainly changed priorities in our lives many times they are at the hospital being with my sister. They really do noed to anond timo rith 
The amount of time the family spends together since the diagnosis is represented in Table XII (p. 58). Slightly more than half (eight) of both the parents and the siblings felt the amount of time together had remained the same as before. Two siblings felt they spent more time together as a family than before the diagnosis and four believed the family spent less time together. The remaining six sets of parents were evenly divided between more or less time. Three believed they spent less time together and three believed they spent more time together.

The brief comments made by the subjects reveal the siblings' understanding of hospital stays and clinic visits. While one parent did mention medical routine as a factor in spending less time together, another parent felt it was a reaction to other family changes and not a response to the sick child's illness. 


\section{CHIIDRENS' PERCEPTION OF FAMILY FEEIING STATES}

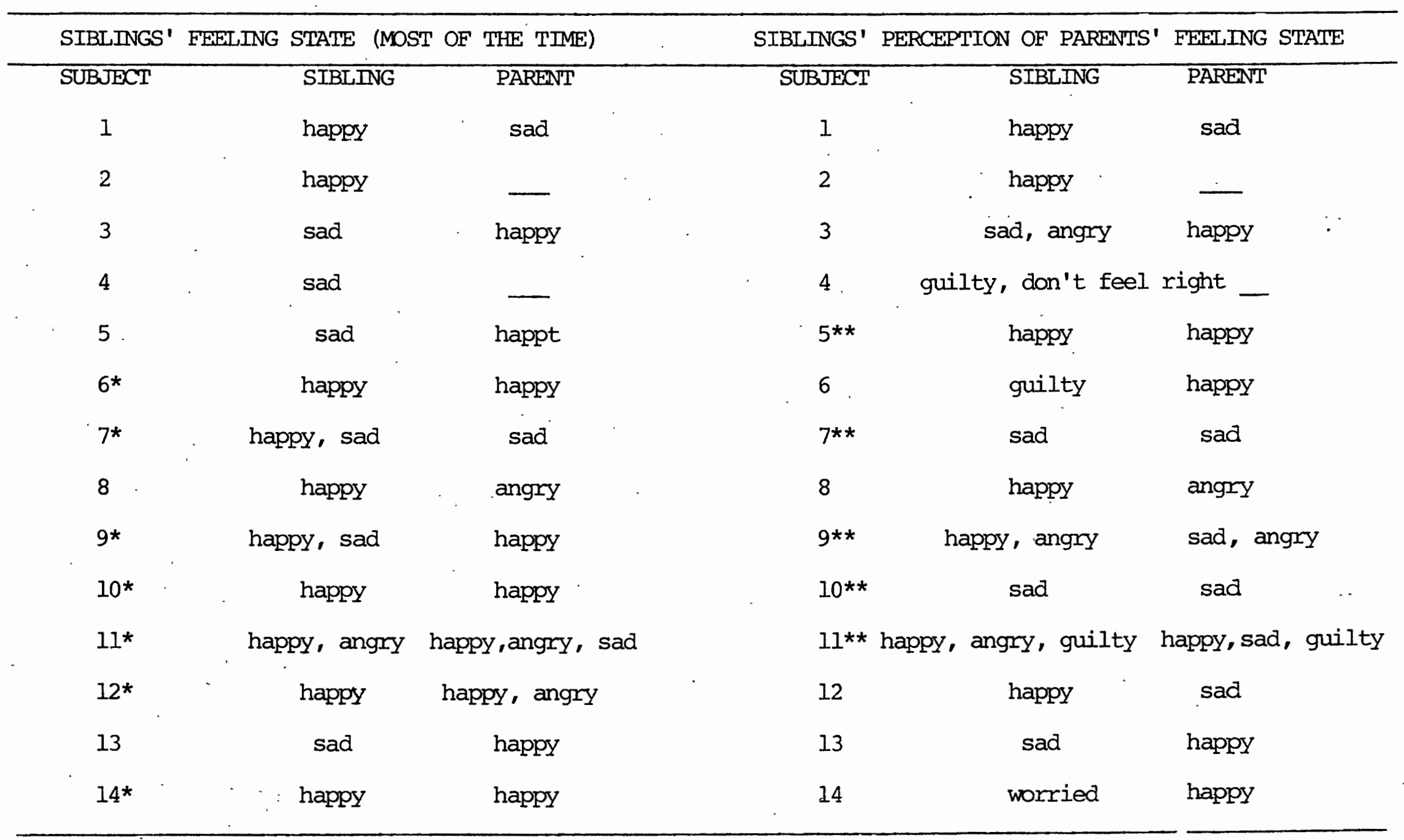

*seven parents were accurate about child's perception of his feeling state most of the time **five parents were accurate about child's perception of their feeling state most of the time (Response was considered accurate if it included one of the same descriptive words as the child's.) 
Table XIII (p.60) again represents the responses to two separate, but related questions. The subjects were asked to indicate the feeling states of the siblings most of the time and of the parents most of the time. While most of the subjects used just one word to describe this feeling state, some included more words to describe differing states. Seven siblings described themselves as basically happy and three used happy in conjunction with sad or angry. Four siblings described themselves as basically sad individuals most of the time and two parents described their children as happy in conjunction with angry and sad. Two parents felt their children were sad most of the time and two failed to respond to this question.

In response to the section on the parent's feeling state five siblings believed their parents were happy most of the time and two felt they were happy and angry. Three siblings believed their parents were basically sad, one replied "sad and angry", two replied "guilty" and another responded "worried". Five parents believed their children saw them as basically happy and one felt the child would see them as "happy, sad, guilty". Four parents believed the children saw them as "sad" most of the time, one as "sad, angry" and one as simply "angry". Two parents did not respond to this question. 
SIBLING'S PERCEIVED CLOSENESS TO PARENTS SINCE DIAGNOSIS

\begin{tabular}{|c|c|c|c|c|c|}
\hline & & \multicolumn{3}{|c|}{ CLOSENESS } & \multirow[b]{2}{*}{$\begin{array}{c}\text { NO } \\
\text { RESPONSE }\end{array}$} \\
\hline & & $\begin{array}{l}\text { NOT AS CLOSE } \\
\text { AS BEFORE }\end{array}$ & $\begin{array}{l}\text { CLOSER } \\
\text { THAN BEFORE }\end{array}$ & $\begin{array}{c}\text { ABOUT } \\
\text { THE SAME }\end{array}$ & \\
\hline $\begin{array}{l}S \\
U \\
B\end{array}$ & SIBLINGS & 1 & 2 & 11 & 0 \\
\hline $\begin{array}{l}\mathrm{E} \\
\mathrm{C} \\
\mathrm{T}\end{array}$ & PARENTS & 3 & 3 & 7 & 1 \\
\hline
\end{tabular}

The sibling's perceived closeness to the parents since the diagnosis is illustrated in Table XIV. The majority of siblings (eleven) felt the closeness remained about the same. Two felt they were closer to their parents since the diagnosis of a serious illness in their brother or sister. Only one sibling felt he was not as close as he had been to his parents before the diagnosis. of the fourteen parent's responses seven believed the level of closeness remained the same, three believed they were less close and three believed they were closer than before the diagnosis was made. One parent failed to respond to this question. 
TABLE XV

SIBLING'S CLOSENESS TO SICK BROTHER OR SISTER SINCE DIAGNOSIS

\begin{tabular}{|c|c|c|c|c|c|}
\hline \multirow{4}{*}{$\begin{array}{l}\mathrm{S} \\
\mathrm{U} \\
\mathrm{B} \\
\mathrm{J} \\
\mathrm{E} \\
\mathrm{C}\end{array}$} & \multirow[b]{3}{*}{ SIBLINGS } & \multicolumn{3}{|c|}{ CLOSENESS } & \multirow{3}{*}{$\begin{array}{c}\text { NO } \\
\text { RESPONSE }\end{array}$} \\
\hline & & $\begin{array}{l}\text { NOT AS CIOSE } \\
\text { AS BEFORE }\end{array}$ & $\begin{array}{c}\text { CLOSER } \\
\text { THAN BEFORE }\end{array}$ & $\begin{array}{c}\text { ABOUT } \\
\text { THE SAME }\end{array}$ & \\
\hline & & 2 & 3 & 9 & \\
\hline & PARENTS & 0 & 5 & 8 & 1 \\
\hline
\end{tabular}

Table XV represents data collected in response to an inquiry about the closeness of the sibling to his sick brother or sister. Nine siblings believed they remained about as close to their sick sibling as they were before the diagnosis was made. Two siblings felt they were not as close as before and three replied that they were closer than before the diagnosis. Eight of the parents believed that the level of closeness between the children had remained the same, while five of them felt the children had become even closer since the diagnosis. None of the parents felt the children were further apart and one parent failed to respond to this question. 
TABLE XVI

SIBLING'S CONCERN FOR OWN HEALTH

\begin{tabular}{|c|c|c|c|c|c|}
\hline \multirow{8}{*}{$\begin{array}{l}S \\
U \\
B \\
J \\
E \\
C\end{array}$} & \multirow{7}{*}{ SIBIINGS } & \multirow[b]{3}{*}{ NEVER } & \multicolumn{3}{|c|}{ FREQUENCY OF CONCERN } \\
\hline & & & & AIL & NO \\
\hline & & & SOMETIMES & THE TIME & RESPONSE \\
\hline & & 2 & 10 & 2 & 0 \\
\hline & & & & & \\
\hline & & & & & \\
\hline & & & & & \\
\hline & & & & & \\
\hline $\mathrm{T}$ & PARENTS & 0 & 13 & 0 & 1 \\
\hline
\end{tabular}

SUBJECTS' BRIEF COMMENTS CONCERNING OWN HEAITH

SUBJECT

5

6

7

11

14
SIBLING

when I get a temperature I worry about being sick
PARENT

once in a while he says he's sick and it's usually around a time when she's receiving medicine and he feels he wants some attention

sometimes, but not now because my mom explained it to me

I might get the same thing

I don't smoke nightmares of illness, (cigarettes or pot) overcautious with colds, I try to stay healthy. etc.

It's got me worried because I eat sugar and chocolate so much. 
The sibling's concern for his own health is addressed in Table XVI (p.64). Once again the responses of the parents and the siblings' were similar. Thirteen parents felt their children were concerned for their own health "sometimes" and one parent failed to respond. Ten siblings replied they were concerned sometimes, while two felt they were never concerned and two replied they were concerned all the time.

In the section reserved for subjects' comments only one of the five siblings comments actually referred to a concern about health in general, maintaining a balanced diet, smoking and having a fever. only two parents commented on this question. One felt the child used a concern over his own health as a means of getting needed attention and the other parent felt the child had become overly cautious about colds, etc. 
TABLE XVII

SIBLING'S DESIRE TO TAKE SICK BROTHER OR SISTER'S PLACE

\begin{tabular}{|c|c|c|c|c|c|}
\hline \multirow{4}{*}{$\begin{array}{l}S \\
U \\
B \\
J \\
E \\
C\end{array}$} & \multirow{3}{*}{ SIBLINGS } & \multirow{3}{*}{$\frac{\text { NEVER }}{6}$} & \multicolumn{3}{|c|}{ FREQUENCY OF DESIRE } \\
\hline & & & SOMETIMES & $\begin{array}{c}\text { ALL } \\
\text { THE TIME }\end{array}$ & $\begin{array}{c}\text { NO } \\
\text { RESPONSE }\end{array}$ \\
\hline & & & 5 & 3 & 0 \\
\hline & PARENTS & 6 & 5 & 1 & 2 \\
\hline
\end{tabular}

\begin{tabular}{ll}
\hline SUBJECT & \multicolumn{1}{c}{ SIBLING } \\
sometimes I feel \\
bad about what she's do \\
going through \\
of course, we her parents \\
3
\end{tabular}


Table XVII (p. 64) addresses the sibling's desire to take his sick brother or sister's place. Responses of parents and siblings were almost perfectly matched. Six parents and siblings indicated they never wanted to take the sick child's place and five of each category felt sometimes they wanted to exchange places with the sick child. Three of the siblings felt they wanted to change places all the time and one parent believed his child wanted to change all the time. Two parents did not respond to this question.

The brief comments made by the siblings reveal two very different reasons for wanting to exchange places with the sick child. Of the seven siblings who commented two indicated they were aware of the pain and unhappiness experienced by their brother or sister and they wished to relieve them. Three of the seven who commented wanted to exchange places in order to get more attention or receive the gifts their brother or sister got. Two of the seven siblings who commented indicated they wouldn't want to exchange places because of the negative aspects of the illness and the required medical regimen. The parents reflected these same ideas in their comments about the siblings exchanging places with each other. 


\section{CHAPTER V}

\section{DISCUSSION AND RECOMMENDATIONS}

Although current literature reveals a recent interest in "death and dying" by the general public and scientists alike, there is still a great deal to learn about this inevitable experience. One significant area of concern is the effect of a child's life-threatening illness or death upon his or her siblings. This study was conducted to gain more data in this complex field of investigation. More specifically, the focus was aimed at the intricate interaction between the parents of a sick child and his or her siblings. The study addressed the following question, in particular: Do the ways in which parents cope with a seriously ill child make a difference in the way siblings view the closeness in the family and their own self-concept?

In order to uncover the ways in which parents cope with the crisis of a life-threatening illness the questionnaire used in this study was specifically designed for the children to answer. Because the same questionnaire, however, was given to the well child and to his parents, as well., it offered a unique opportunity to compare and analyze their responses. The parents were asked to reply as they felt their well child would answer their 
perception of the well child's environment and interaction during this period of crisis.

As the literature points out, a person is not so much influenced by the actual or intended behavior of someone else, as he is by his perception of that person's behavior. This is true for both the parents and the child. The child may perceive the parents as disinterested and rejecting of him, when in fact, they are frightened., confused and often overwhelmed by the crisis facing them. Parents are just as prone to misunderstanding and misinterpreting their children's behavior. If a well child suddenly becomes rebellious and difficult to manage his parents may perceive him as an insensitive troublemaker, when, in his own way, he is actually seeking reassurance and comfort. Therefore, it was important in this study to deal with the child's perception of the events surrounding the life-threatening crisis rather than with the "facts". By asking parents to answer as they believed their child would it was possible to assess how "accurately" the parents interpreted events from the child's point of view. Assuming that successful parental coping must include understanding the events from the child's point of view, it would be possible to assess these coping patterns and their effect upon the child. 
upon the child.

The most obvious point to be seen from even a cursory review of the data is the striking similarity of the responses by both parents and siblings. In many cases the number of replies for a particular question were within one number of each other or matched exactly. For example, in response to the sibling's desire to know of the illness thirteen parents and thirteen siblings answered "sometimes". Five siblings and five parents felt the siblings and nine parents believed it had remained about the same. This pattern held throughout most of the survey.

The similarity of responses in this survey indicates a high degree of "accuracy" and understanding on the part of the parents, an essential ingredient of successful parental coping. As was pointed out in the literature review, Nagera believes children are influenced far more by the actions of their parents during stressful periods than by the condition of their ill sibling. 1 If parents understand how their children are perceiving events during the crisis they have the basis for assisting their children to successfully cope.

Another indicator for successful family coping in life-threatening crises was given in the literature review by Kaplan. He feels the ability of the parents to 
communicate the seriousness of the illness to the family and to establish an open, honest environment in which to share information is essential in lessening the impact of severe illness on families. ${ }^{2}$ He believes the optimal period to establish this pattern is during the early, acute stage of the crisis. The data from this survey reveals the majority or parents (thirteen) and siblings (twelve) felt open, honest communication began within the first few weeks. Thirteen siblings indicate they wanted to be told about the serious diagnosis and twelve parents revealed their understanding of the child's need to know by also responding affirmatively. Another indication of open, honest communication in these families, is the eleven negative sibling responses to an inquiry about any further questions they might have concerning the illness. Eight parents replied negatively, two indicated they thought their child might have more questions and four left this space blank. It appears that for this population the majority of families have initiated the recommended open communication within the critical first few weeks after diagnosis. (It must be remembered, however, that the data is skewed toward greater communication by the fact that only families in which the siblings had been told of the diagnosis were included in the study.) 
These families have also adjusted well to the difficulties of a life-threatening crists as evidenced by the satisfaction of family members in regard to frequency of discussions about the illness. According to Turk many families establish a "web of silence" to prevent uncomfortable discussions concerning the illness and its prognosis. ${ }^{3}$ other families may become so preoccupied with the illness that they lose sight of the other aspects of their lives. The families included in this survey revealed that both parents (thirteen) and siblings (thirteen) felt they discussed the illness and its ramifications "sometimes". When asked how often they wanted these discussions eight siblings and ten parents replied they wished the frequency to reamin the same. There was no overwhelming evidence on the part of either the parents or the siblings to warrant changing the existing communication patterns.

As an indication of how much change the siblings had experienced since the diagnosis they were asked to indicate any changes in responsibility, school life, visits with friends in general, family time spent together and time spent alone with parents. In all of these areas the majority of siblings and parents believed the changes, if any, ahd been minimal. Their written comments indicated that some changes were expected as 
the children matured and were not necessarily related to the illness. The parents' highly "accurate" rate of identifying the siblings' responses again points to the ability of these parents to understand and empathize with their children.

If it is true that these families are satisfied with the patterns of communication, that the parents have made successful efforts to accept the difficulties of the crisis and are coping adequately with the problems encountered by their children, then, according to the literature, one would expect relatively well-adjusted children with few of the disturbed reactions found by Cain and his co-workers. ${ }^{4}$. For the families of this survey the data supports the conclusion as evidenced by the responses to treatment of siblings and sick children feeling states most of the time, closeness to parents and sick child by sibling and concerns for sibling's own health. When asked how they felt they had been treated by their parents since the diagnosis the majority of siblings (twelve) replied with positive responses. Although most siblings felt their sick brother or sister had been treated in a special way, only two defined this attention in a negative manner as "spoiled". The parents, however, were not as comfortable about the situation. The majority of parents (nine) felt the 
siblings believed the sick child had received a disproportionate share of attention. Some parents worried that the siblings would feel that too much had been expected of them throughout the crises. Despite the parents' doubts the children reflected a sense of well-being with little of the jealousy or rivalry described in the literature.

Another indication of successful adaptation to the life-threatening crisis by the siblings is their response to the question about their feeling state most of the time. Ten siblings considered themselves basically unhappy. Nine parents felt their child would indicate he or she was happy most of the time, two did not respond and two felt their child was unhappy most of the time. If happiness and satisfaction are accepted as indicators of successful coping with a stressful situation then these children and their parents have developed adaptive coping skills.

The closeness of the family as perceived by the siblings also supports the conclusion that these parents are coping in positive ways with the life-threatening crisis. The majority of siblings felt that the closeness to their parents had remained the same (eleven) or was greater than before the diagnosis (two). Only one child did not feel as close. The majority of parents (ten) 
also saw the closeness in positive terms and only three felt the children would respond "not as close as before". This same sense of closeness existed between the sibling and his sick brother or sister. Twelve siblings felt the closeness was the same or greater since the diagnosis. Thirteen parents felt the children would feel the same or closer. At this point we can only speculate about how close "the same as before" really is. However, it can be said that the illness and the ways in which the parents have coped have not had an overall negative effect on the family closeness for the majority of siblings.

One final indication of the lack of disturbed reactions can be found in the siblings' response to a concern for their own health. According to Cain, children often become obsessed with fears of "catching something" or they develop hospital and doctor phobiaz after observing the necessary medical treatment of their sick brother or sister. ${ }^{5}$ Twelve of the siblings indicated they were either "never" concerned (two) or were concerned only "sometimes" (ten). Two siblings replied they were concerned "all the time". The majority of parents (thirteen) believed their children would respond that they were concerned "sometimes" and one parent did not answer the question. 
In summary, it can be said the data reveals a group of families, the majority of which have successfully adapted to a life-threatening crisis. Evidence exists which supports the theory of early, open communication as a major means of lessening the impact of serious childhood illness on siblings and family alike. These families have met the criteria established by Kaplan (p. 6) for successful coping responses and the majority of siblings exhibit healthy, well-adjusted attitudes in response to the illness.

The highly successful coping rate these families exhibited was unexpected when this study began. Although it was not a part of the study design to uncover why the families have managed so well, several factors may have played a part. While interviewing the families they often mentioned the co-operative, interested assistance they received from the staff at the oncology/ Hemotology clinic. The majority of parents felt their questions had been answered thoroughiy and that the staff was aware of the impact the diagnosis had upon the entire family. Dr. Neerhout, as director of the clinic, must be given credit for establishing an atmosphere in which the families felt comfortable and could gain the medical information necessary as a basis for successful family adaptation to a life-threatening crisis. 
Some of the families also mentioned talking with a Child Life Therapist assigned to the Pediatrics Department. It is unsure how many families were counseled by these therapists and the amount of counseling they received. To some extent, however, these therapists may have been a positive influence upon the families seen in the clinic.

A final factor in the high level of coping found in most of the families may have been their participation in a parents' group called Candlelighters. This group was originally organized as a support group for parents of children with cancer, but the parents of children with other life-threatening illnessess have occasionally been involved. Although some of the parents were founders of this group and are still quite active, it is not certain how much all of the families have participated. The support and the information shared by the families through the Candlelighters, however, must have added to the confidence and the ability to cope found in these families.

In closing, it is recommended that families of recently diagnosed children be screened as soon as possible for communication difficulties. Within the first week or two following diagnosis families establish patterns of 
communication about the illness which are crucial to adaptive coping and stress outcome. In this early, acute stage of the crisis professional intervention, if necessary, can prevent Turk's crippling "web of silence" or the equally detrimental all-consuming interest in the illness. 
CHAPTER . V--NOTES

1. Humberto Nagera, "Chilaren's Reactions to the Death of Important objects", The Psychoanalytic Study of the Child, Vol. XXV, International University Press, Inc., New York, 1970.

2. David M. Kaplan, Rose Grobstein and Aaron Smith, "Predicting the Impact of Severe Illness in Families", Health and Social Work, Vol. 1, no: 3 (August, 1976), pp. 472-481.

3. C.M. Binger, "Childhood Leukemia: Emotional Impact on Patient and Family", New England Journal of Medicine, (February 20, 1969), pp.414-417.

4. Albert C. Cain, I., Fast, and Mary E. Erickson, "Childhood Disturbed Reactions to the Death of a Sibling", American Journal of Orthopsychiatry, Vol. 34, pp. 741-752.'

5. Kaplan, op.cit. 


\section{BIBLIOGRAPHY}

Arthur, B. and Kermme, M.L., "Befeavement in Childhood", Journal of Child Psychology and Psychiatry, 5 (1964), pp. 37-49.

Bard, M. And Sutherland, A.M. (1955), Psychological Impact of Cancer and Its Treatment", Cancer, 8:656-672.

Binger, C.M., Arlin, R.R., Feuerstein, R.C., Dushner, J.H., Soger, S., and Mikkelsen, C., (1969), "Childhood Leukemia, Emotional Impact on Patient and Family" , New England Journal of Medicine, 280:414-418.

Bowlby, John, Childhood Mourning and Its Implications for Psychiatry, Macmillan, New York; 1973.

Braur, Paul H., M.D. Cockerill, Eleanor, Katner, Bernard, PhD. , A Constructive Approach to Terminal Illness, 1972 .

Burton, Lindy, The Family Life of Sick Children: A Study of Families Coping With Chronic Childhood Disease, Routledge and Kegan Paul, Ltd. 1975.

---- Care of the Child Facing Death, Boston, Routledge and Kegan Paul, Ltd, 1974.

Cain, A.C., and Cain, B.X. (1964), "On Replacing a Child", Journal of the American Academy of Child Psychiatry, vol. 3, pp. 443-456.

--- Fast, I. and Erickson, M.E., (1964), "Children's Distrubed Reactions to the Death of a Sibling", American Journal of Orthosphychiatry, Vol. 34 , pp. 741-752.

Coyle, Grace L., "Concepts Revelant to Helping the Family as a Group", Social Casework, Vol. 43, no. 7 (July, 1962).

Dana, B., et al, Catastrophic Illness: Impact on Families Challenge to the Professions, Cancer Care, Inc. Symposium, Oct. 6, 1966, New York.

Dávidson, J. (1968), "Infantile Depression in a Normal Child", Journal of the American Academy of Child Psychiatry, Vol. 7, pp. 522-527. 
Debuskey, M. (1970), The Chronically IIl Child and His Family, Charles Thomas, Illinois.

Dumont, R.G. and Foss, D.C., (1972) The American View of Death: Acceptance or Denial, Cambridge, Mass., Schenkaman Publishing Co., Inc.

Easson, W.M. (1968), "Care of the Young Patient who Is Dying", Journal of the American Medical Association, Vol. 205:203-207.

Feinberg, D. (1970), "Preventive Therapy With Siblings of a Dying Child", Journal of the American Academy of Child Psychiatrists, Vol. 9., pp. 664-668.

Freud, Anna,. (1969), "The Concept of the Rejecting Mother", in Indications for Child Analysis and Other Papers, Hogarth Press, London.

Freud, Sigmund, (1957), "Mourning and Melancholia", Standard Edition, London:Hogarth Press.

Friedman, S.B., et al, "Behavioral Observation on Parents Anticipating the Death of a Child", in Robert Noland, ed.Bereavement? Parents of the III and the Handicapped, Charles C. Thomas, (1971) Springfield, Ill.

Glasser, B.G. and Strauss, Anselm, Awareness of Dying, Aldine Publishing Company, Chicago, Ill. 1965.

Goldberg, S.B. (1973), "Family Tasks and Reactions in the Crisis of Death", Social Casework, Vol. 54, no. 7 (July) pp. $389-4 \overline{05}$.

Grollman, Earl A. Explaining Death to Children, Beacon Press: Boston, 1969.

-..- Talking About Death: A Dialogue Between Parent and Child, Beacon Press, Boston, 1970.

Gyulay, Jo-Ellen, "The Forgotten Grievers", American Journal of Nursing, Vol. 75, no. 9, pp. 1476-1479, (Sept. 1975).

Harrison, S.I., Davenport, C.W. and McDermott, J.F. (1967), "Children's Reaction to Bereavement, Archives of General Psychiatry, Vol. 17. pp. 593-598. 
Hilgard, J. (1969), "Depressive and Psychotic states on Anniversaries of Sibling Death in Childhood", Internal Psychiatry Clinics, Vol. 6, no. 2, pp. 197-211.

Hill, Reuben (1965), "Generic Features of Families Under Stress", in Crisis Intervention: Selected Readings, Family Service Association of America, New York.

Kalish, Richard A. (1969), "The Effects of Death Upon the Family", Death and Dying, Cleveland and London: The Press of Case Western Reserve University.

Kaplan, D.M., Smith, Aaron, Grobstein, Rose, Fishman, Stanley E. (1973), "Family Mediation of Stress", Journal of Social Work, Vol. 18, pp. 444-449.

----- (1970), "The Impact of Childhood Leukemia on Families", Science Writer's Seminar, American Cancer Society.

-.-- (1976), "Predicting the Impact of Severe Illness in Families", Health and Social Work, (July, 1973) Vol. 18, no. 4, pp. 70-75.

Kastenbaum, R.J., Death, Society and Human Experience, C.V. Mosby Co., St. Louis, 1977.

Knapp, Vridna S. and Hansen, Howard., "Helping the Parents of Children with Leukemia", Social Work, (July, 1973), Vol. 18, no. 4, pp. 70-75.

Koenig, R.R. (1968), "Fatal Illness: A Survey of Social Service Needs", Journal of Social Work, Vol. 13, pp. 432-438.

Kubler-Rose, E. (1969), On Death and Dying, New York, Macmillan.

Lang, P.A., and Oppenheimer, J.R., "The Influence of Social Work When Parents are Faced with the Fatal Illness of a Child", Social Casework, (March, 1968), pp.161-166.

McCarthy, E. (1969),"The Repercussions of the Death of a Child", Proceedings of the Royal Society of Medicine, Vol. 62, pp. 553-554. 
Molfi, Mary W. "Families in Grief: The Question of Casework Intervention", Social Work, Vol. 12, no. 4, pp.40-45.

Montefiore, Cannon H., et al, Death Anxiety, MSS Information Corporation, New York, (1973).

Nagera, Humberto, (1970), "Children's Reactions to the Death of Important objects", The Psychoanalytic Study of the Child, Vol. XXV, International Universities Press, Inc. New York.

Oppenheimer, Jeanette R., "Use of Crisis Intervention in Casework with the Cancer Patient and His Family", Social Work, April, 1967, Vol. 12, no. 2, pp.44-5.2.

Pincus, I., Death In the Family, New York, Pantheon Press, 1975 .

Pollock, G.H., (1962), "The State of Crisis: Some Theoretical Considerations", Crisis Intervention: Selected Readings, Howard J. Parad, ed., New York, Family Service Association of America.

Rapoport, L. (1965), "The State of Crisis: Some Theoretical Considerations", Crisis Intervention: Selected Readings, Howard J. Parad, ed., New York, Family Service Association of America.

Rosenblatt, Bernard, "A Young Boy's Reaction to His Sister's Death", Journal of the American Academy of Child Psychiatry; Vol. 9, pp.321-325.

Spiegel, John P., The Threat of Impending Disaster, Macmillan, New York, (1964).

Smith, A.G. and Sneider, L.T., "The Dying Child: Helping the Family Cope with Impending Death", Clinical Pediatrics, Vol. 8, (March, 1969)., pp. $\overline{131-134 .}$

Weiner, Jerry M. (1970), "Reaction of the Family to the Fatal Illness of a Child", Loss and Grief: Psychological Management in Medical Practice, Bernard Schoenberg, A.C. ed., New York: Columbia University Press.

Wolfenstein, M. (1957), Disaster, Blencoe, I11., The Free Press. 
APPENDIX A

SPECIAL CONSENT FORM 
SPECIAL CONSENT TO STUDY THE EFFECTS OF A CHILD'S SERIOUS ILLNESS UPON HIS/HER SIBLINGS

I hereby authorize Kathleen Bales, Masters Degree Candidate in Social Work at Portland State University, to administer a questionnaire to my

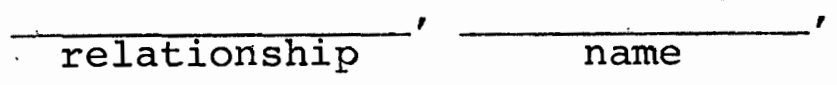

on - I understand the purpose of this questionnaire date

is to gather and evaluate data concerning the effects of a child's serious illness on his/her siblings. I also understand this research project is being conducted to partially fulfill Portland State University's requirements for a Masters Degree in Social Work and that the data complied from this study will be presented as a research practicum to the school of Social Work, Portland State University. I understand this study will be conducted under the direction of Jack Hegrenes, Ph.D., Associate Professor, Crippled Children's Division, Child Development and Rehabilitation Center, University of Oregon, Health Sciences Center, Adjunct Professor, School of Social Work, Portland State University and in confunction with Robert Neerhout, M.D., Chairman of Department of Pediatrics, University of Oregon, Health Sciences Center.

I understand this project may result in information which is beneficial to professionals offering care to the seriously sick child and his family. It may also provide useful information for parents in the areas of child management and coping with 
serious illness in the family, therefore, the data gathered in this study may be published at a later date or otherwise disseminated.

I understand throughout this project my identity and that of my child will remain confidential. At no time will our names appear either on the questionnaire itself or in the subsequent compilation and dissemination of information gathered through this study.

I understand the administration of this questionnaire will require no more than one hour of my child's time and will be conducted at my convenience, At any time I may withdraw my permission for my child's participation in this project without jeopardizing the medical care of my sick child.

I understand through the administration of this questionnaire my child will not receive additional information concerning the condition of his sick brother or sister. I certify that. I have read the questionnaire and understand its purpose and intent. I also understand I am free at any time to ask questions concerning this project and its effect upon my child.

Signed

Relationship

Date 
Signed

Relationship

Date

Witness

Date 
APPENDIX B B

QUESTIONNAIRE 
QUESTIONNAIRE

1) Age

2). Sex

3). Number of brothers and ages

4) Number of sisters and ages

5). Age of brother or sister who is sick

6) How long have you known about your brother or sister's

\section{illness? Circle one answer.}

A. Six months or less B. One year

C. three years or more D. Don't know

7) Who first told you of your brother or sister's illness? Circle one answer:
A. Mother
B. Father
C. Both mother and father
D. Ill brother or sister E. Other family member
F. Doctor or other health professional

8) How soon after your brother or sister got sick were you told? Circle one answer.
A. Immediately
B. A few weeks
C. a year or more
D. Don't know

9) Did you think your brother or sister was seriously ill before you were told?
A. Yes
B. No.

10) Did you want to be told about your brother or sister's illness? Circle one.
A. Yes
B. No 
Questionnaire

11) Do you talk to your family now about your brother or sister's illness? Circle one.
A. Never
B. Sometimes
C. Frequently

12) Do you talk to your sick brother or sister about his or her illness? Circle one.
A. Never
B. Sometimes
C. Frequently

13) How much do you want to talk about your sick brother or sister? Circle one answer.
A. More than I do now. B. Less than I do now.
C. About the same

14) Have you at any time talked to a doctor or other health professional about your brother or sister?
A. Yes
B. No

15) If so, was this talk helpful?
A. Yes
B. No
C. Not applicable

16) Do you have questions about your brother or sister which no one has answered for you?

A. Yes. B. No

Briefly explain

17) Have your responsibilities changed since your brother or sister became ill?
A. More responsibility than before
B. Less responsibility
than before
C. About the same
Briefly explain 
Questionnaire

18) Has your life at school changed since your brother or sister became ill? Circle one.
A. None
B. a little
c. a. lot
D. completely
Briefly explain

19) How often do you see your friends since your brother or sister got sicd? Circle one.
A. More than before
B. Less than before
C. About the same as before
Briefly exolain

20) Do you help care for your brother or sister when he or she is sick?
A. Yes
B. No

21) Do you want to help care for your brother or sister when he or she is sick?
A. Yes
B. No

22) Since your brother or sister got sick how do you think you are treated?

Briefly explain

23) Since your brother got sick how has she or he been treated?

Briefly explain 
Questionnaire

24) How much time does your family spend together since your brother or sister got sick?
A. More time than before
B. less time than before
C. About the same as before
Briefly explain

25) How much time do your parents spend with you alone since your brother or sister got sick?
A. More time than before B. Less time than before
c. about the same as before
Briefly explain

26) How much time do you and your family have for recreation since your brother or sister got sick?
A. Nore time than before
B. Less time than before
c. About the same as before

27) How do you feel most of the time?
A. Happy
B. Sad
C. Angry
D. Guilty

28) How do you think your brother or sister feels most of the time?
A. Hapoy
B. Sad
C. Angry
D. Guilty

29) How do you think your parents feel most of the time?
A. Happy
B. Sad
C. Angry
D. Guilty 
Questionnaire

30) How do you feel about your sick brother or sister most of the time?

A. Closer than before B. Not as close as before

C. About the same as before

Briefly explain

31) How do you feel about your parents most of the time?
A. Closer than before B. Not as close as before
C. About the same as before
Briefly explain

32) Do you think about your own health since your brother or sister got sick?

A. Never B. Sometimes C. All the time

Briefly explain

33) Do you sometimes wish you could take your sick brother or sister's place?
A. Never
B. Sometimes
C. All the time

Briefly explain 